\title{
Tenant Mix and Retail Rents in High Street Shopping Districts
}

\section{Song Zhang ${ }^{1}$ (i) $\cdot$ Mark van Duijn ${ }^{1}$ (i) . Arno J. van der Vlist ${ }^{1}$ (i)}

Published online: 03 July 2020

(C) The Author(s) 2020

\begin{abstract}
Urban areas have long had shopping districts in which retail properties are concentrated. It is argued that the diversity of retail tenants, often called tenant mix, contributes to the image and attractiveness of the high street shopping district. These districts are characterized by fragmented ownership and therefore the tenant mix is outside the control of individual property investors. We aim to explore the relationship between tenant mix and retail rents by studying high street shopping districts in the Netherlands. We start with delineating high street shopping districts using granular data on the spatial distribution of retail jobs. Within each shopping district, tenant mix is measured using detailed information on SBI sector classification and the number of retail properties. We find shopping districts with greater tenant mix show higher retail rents compared to districts with lower tenant mix.
\end{abstract}

Keywords Tenant mix · Shopping externalities · High street retail ·

Difference-in-difference

\section{Introduction}

Shopping districts are prevalent in urban areas. Shopping districts are areas where retail properties and retail activities concentrate. The diversity of retail tenants in a shopping district is called tenant mix and it determines the variety of goods and

Song Zhang

song.zhang@rug.nl

Mark van Duijn

mark.van.duijn@rug.nl

Arno J. van der Vlist

a.j.van.der.vlist@rug.nl

1 Real Estate Centre, Department of Economic Geography, Faculty of Spatial Sciences, University of Groningen, PO Box 800, 9700 AV, Groningen, The Netherlands 
services that a shopping district can provide to consumers. It is well known in the retail industry that tenant mix is an important factor which contributes to the image and attractiveness of a shopping district.

Tenant mix of a shopping district is important to consumers because they prefer a shopping district with a wide variety of goods and services, relative to one with less variety (Glaeser et al. 2001). By visiting shopping districts that provide various goods and services, consumers have more choices and they can save on out-of-pocket costs and time costs (Stahl 1982; Claycombe 1991; Brueckner 1993; Teller and Reutterer 2008). Tenant mix is also important to retail tenants, because of the existence of shopping externalities (Brueckner 1993; Wheaton 2000; Koster et al. 2014). A retail tenant may benefit from footfall, i.e. number of visitors, brought about by other retail tenants in their proximity. For example, a café on the corner benefits from nearby shops in the same shopping district, as consumers who just finished shopping may stop by for a drink. This shopping externality is especially important for small retail tenants because they greatly rely on footfall generated by other, especially anchor, retail tenants (Benjamin et al. 1992; Brueckner 1993; Gatzlaff et al. 1994; Miceli and Sirmans 1995; Colwell and Munneke 1998; Pashigian and Gould 1998). If tenant mix affects the image and attractiveness of shopping districts, it is likely that this is capitalized into retail rents (Pashigian and Gould 1998; Cho and Shilling 2007; Arzaghi and Henderson 2008; Ahlfeldt et al. 2015).

Most existing papers on the relationship between tenant mix and retail rents consider shopping malls (Eaton and Lipsey 1982; Abratt et al. 1985; Sirmans and Guidry 1993; Gerbich 1998; François et al. 2005; Des Rosiers et al. 2009; Yuo et al. 2010). In shopping malls, property investors control both tenant mix and rents simultaneously, resulting in tenant mix being endogenous by nature. The owner of a shopping mall manages each unit and chooses the optimal tenant mix by distributing units and space to tenants to maximize expected returns of the mall (Gould et al. 2005; Des Rosiers et al. 2009; Yuo et al. 2010). This is very different from the situation in high street shopping districts. In high street shopping districts, ownership of retail properties is usually fragmented so that tenant mix is exogenous to individual property investors. At the same time, tenant mix is also exogenous to retail tenants. In high street shopping districts, tenant mix largely predates any tenant's decision to rent a retail property, so it cannot have been influenced by determination or negotiation over the retail rents. High street shopping districts provide a useful context to address the relationship between tenant mix and retail rents.

Relative few studies consider retail rents in high street shopping districts. Koster et al. (2019) examine the relationship between footfall and retail rents for high street retail. While they use a clever identification strategy based on spatial variation in footfall, the strategy is essentially based on cross-sectional variation in footfall to time-varying rents. Also, they base their analysis on a limited footfall dataset which is only collected twice-a-year for a couple of hours. Teulings et al. (2018) investigate the land use structure in shopping districts and find a distance decay in retail rents from the center of a shopping district. However, the shopping districts that they use were based on the government's land use plan, and thus time invariant, which may not reflect the real and dynamic concentration of retail properties. 
Motivated by the above concerns, we examine the relationship between tenant mix and rents for high street shopping districts. One key challenge in our analysis is to identify geographic areas that precisely reflect shopping district boundaries, shapes and sizes, in order to measure the tenant mix within each shopping district. Shopping districts do not necessarily follow boundaries, shapes and sizes of intended land use designations, which may introduce measurement error by incorrectly assigning a retail property as being inside or outside a particular district (for similar discussions for enterprise zones, see Neumark and Kolko (2010). To construct accurate shopping districts, we utilize granular data of all retail properties registered at the Dutch Chambers of Commerce. This dataset is collected on a yearly basis, and it comprises information about every retail property's address, SBI sector classification, ${ }^{1}$ and number of jobs. For every year between 1996 and 2011, we define grids and calculate the density of retail properties for each grid. Adjacent grids are merged to form a cluster if the retail property density of each grid exceeds a threshold. This results in a large number of shopping districts and information about the development of those shopping districts - in terms of boundary, shape, size, number of retail properties and number of jobs - between 1996 and 2011.

For each shopping district, we calculate the tenant mix by using the SBI sector classification and number of retail properties in each classification. We analyze the relationship between tenant mix and retail rents by combining this with data containing information on 6,864 retail rental transactions in the Netherlands between 1996 and 2011. For each of the rental transactions we can identify at any given year whether a retail property falls within a shopping district. Our analysis starts with investigating the functional form of the relationship between retail rents and tenant mix, while controlling for observed heterogeneity. We analyze both linear and semiparametric functional forms to elicit the relationship between tenant mix and retail rents. Next, we estimate a difference-in-difference model to test for unobserved heterogeneity in retail rents. We will show that the heterogeneity in retail rents are largely explained by the variation in the tenant mix of shopping districts.

Our paper extends the literature in several ways. First, we contribute to the literature on the relationship between tenant mix and retail rents. While the role of tenant mix in determining rents has been noticed long before, most existing literature examines shopping malls. We examine the relationship by considering high street shopping districts in the Netherlands. Second, we contribute to the literature of shopping districts using granular data on retail properties. We exploit information on SBI sector classification to distinguish retail activities. This study is one of the first papers to measure the dynamics of tenant mix in this manner, which connects to the literature on agglomeration and coagglomeration economies. We complement information on shopping districts with data on retail rents in the Netherlands and show that retail tenants do not only benefit from the agglomeration of shops, but also that tenant mix in such agglomerations is an important driver explaining retail rents. Third, our findings

\footnotetext{
${ }^{1}$ SBI sector classification is a hierarchical classification of economic activities that CBS (Statistics Netherlands) uses to classify business units according to their main activity, like NAICS for the U.S. For more information about SBI sector classification, see https://www.cbs.nl/-/media/_pdf/2018/01/ sbi-2008-versie-2018-engels.pdf.
} 
have important practical implications for shopping districts. We provide empirical evidence showing that tenant mix is positively related to retail rents, and that shopping districts' variety of goods and services is capitalized into retail rents. To increase the tenant mix of a shopping district may be an effective way to improve the attractiveness of the shopping district and thus to elevate consumers, retail tenants and investors' benefits.

The paper is organized as follows. Section "Retail in Shopping Districts" discusses the relationship between tenant mix and rents. Section "Data" describes the data used in our empirical research. Section "Empirical Model" presents the empirical model and "Results" presents baseline regression results. In "Sensitivity Analysis", we provide a series of sensitivity analyses. Section "Conclusion" provides a conclusion.

\section{Retail in Shopping Districts}

\section{Retail Market}

The retail market we consider is part of an urban economy in which retail properties are unevenly distributed across space as they concentrate in shopping districts. We assume that in each shopping district there are two types of agents, namely retail property investors and retail tenants. Retail property investors own retail properties while retail tenants rent properties from investors. Retail tenants provide various goods and services to consumers. ${ }^{2}$ Both investors and retail tenants can freely enter or exit any of the shopping districts. The retail rental market we consider is competitive.

The theoretical framework we envision is based on a matching function that represents a two-sided search process of investors and tenants. ${ }^{3}$ Investors with vacant retail properties searching for potential tenants in the same shopping district must use a time-consuming and costly search process, while retail tenants looking for a location must go through a similar process when attempting to find a retail property to be located in. After being matched, retail property investors and retail tenants determine retail rents by Nash bargaining. Upon signing the rental contract, the investor receives rental income. In the competitive equilibrium state, both retail property investors and retail tenants maximize their profits.

Tenant mix plays an important role in the matching process as it affects the production or turnover of a retail tenant. First, shopping districts with high tenant mix are able to attract more consumers. Consumers generally aim to minimize the costs for their shopping trips. Shopping districts with high tenant mix can reduce consumers' time and transportation costs (Stahl 1982; Claycombe 1991; Brueckner 1993; Teller

\footnotetext{
${ }^{2}$ For simplicity, we assume each property investor owns one property only and all retail properties are homogeneous to each other, which will not affect the conclusion.

${ }^{3}$ A more formal description of the model is relegated to Appendix A.
} 
and Reutterer 2008) by providing them with a wider variety of goods and services, thus enabling them to complete their shopping within a single shopping trip. When a shopping district has more consumers, the turnover of retail tenants in this shopping district will also be higher. Second, for each retail tenant within a shopping district, they can benefit from the shopping externalities generated by others. Especially for small retail tenants without consumer drawing power, their turnover may depend heavily on the footfall generated by other retail tenants. With higher turnover, retail tenants will be willing to pay higher rents. Meanwhile, from investors' perspective, although individual investors cannot control the tenant mix of a shopping district, they do take tenant mix into consideration when they make decisions whether to buy a property or not. Investors' demand for retail properties located in a shopping district with high tenant mix will push up the cost of owning a property. Consequently, investors will ask for higher rents in return. Pulling these perspectives together, we conjecture that retail rents are positively related to a shopping district's tenant mix.

\section{Retail Planning in the Netherlands}

Retail land use in the Netherlands is subject to urban planning. The urban planning regulatory framework in the Netherlands includes three levels - national, regional and local - of policy instruments. These interconnected instruments reflect the societal preferences regarding land use and govern local planning decisions. Dutch retail planning has had to adhere to rather restrictive national retail planning regulations. According to national retail planning regulations, retail property is only allowed in designated retail zones (Evers 2002).

National retail planning in the Netherlands liberalized since 2004. Regional planning authorities responded by reinstalling the main restrictive elements of the previous national retail planning model at the regional level (Van der Krabben 2009). While retail planning in the Netherlands is implemented at the local level, development of new retail properties must align and comply with regional planning rules. Also, development of new retail properties outside existing retail zones typically requires a change in zoning plans which, when compared to observations of shopping districts in many other countries, ${ }^{4}$ is rather unlikely (Van der Krabben 2009; Nozeman and Van der Vlist 2014). This makes land use rather persistent in the Netherlands.

However, it is noteworthy that designated retail zones reflect only the intended retail land use but not the actual retail land use. Indeed, they are different from the shopping districts defined in our paper which refer to areas where retail properties actually concentrate. Moreover, shopping districts are not invariable, as development of new retail properties changes the landscape of shopping districts all the time. Therefore, in the next section, we will propose and discuss a method which can reflect the actual retail land use and its development. This enables us to observe changes in the boundaries, shapes and sizes of shopping districts in the Netherlands.

\footnotetext{
${ }^{4}$ For instance, France, Portugal, Spain, Turkey, or the U.S.
} 


\section{Data}

We mainly use two datasets for our empirical analysis in this paper. The first dataset contains granular data of all retail properties registered at the Dutch Chambers of Commerce from 1996 to 2011. This dataset is used to construct shopping districts and calculate tenant mix for each shopping district. The second dataset comprises information of retail rental transactions in the Netherlands, also from 1996 to 2011. These rental transactions are matched with shopping districts, based on their transaction year and geographical location.

\section{Shopping District}

Shopping districts are concentrations of retail properties in urban areas. However, the precise boundary of a shopping district is difficult to identify. The existing CBS land use data provide information about designated retail zones, but, as discussed above, they do not reflect the actual retail land use and are not updated to incorporate the most recent development of retail land use. The precise identification of shopping district boundaries, as well as how they change over time, plays a central role in our approach. Therefore, we use Geographical Information System (GIS) techniques to delineate shopping districts boundaries, with the help of granular data for all retail properties registered at the Dutch Chambers of Commerce. The granular data are collected yearly and contain information on each retail property's precise address, SBI sector classification and the number of jobs between 1996 and 2011.

We construct shopping districts, based on the density of retail properties, as follows. ${ }^{5}$ First, we create grids of 10 by 10 meters for the whole Netherlands. Next, for each grid, we calculate the density of retail properties within 100 meters of the grid by using the method of kernel density. When calculating the density, we take the number of jobs at each retail property as the weight for each property. ${ }^{6}$ Finally, we choose a predetermined threshold of density and merge adjacent grids with density exceeding this threshold ${ }^{7}$ to create a shopping district. We apply this procedure to construct shopping districts for every year between 1996 and 2011. Appendix B

\footnotetext{
${ }^{5}$ This methodology is commonly used in applied geography, and has been used to delineate, for example, retail site location selections (Roig-Tierno et al. 2013), retail center attractiveness and catchment areas (Dolega et al. 2016), and retail clusters (Lloyd and Cheshire 2017; Teulings et al. 2018). Other applications outside retail market analysis include delineation of nature (Daams et al. 2016) and office clusters (Van der Vlist et al. 2019).

${ }^{6}$ The choice of using number of jobs as the weight of each retail property has practical reasons. We experimented both with the weights and without the weights. When no weights are used, grids located at the edge of a shopping district usually have a low density value, which makes the shopping districts constructed smaller than their actual size. This has serious consequences in the later stage of our empirical analysis, because retail properties at the edge of a shopping district are often excluded from the corresponding shopping district. However, when the weights are used, this problem is relieved.

${ }^{7}$ We set this threshold of density to be 3,421 jobs per $\mathrm{km}^{2}$, which is equivalent to the 65 th percentile of the retail property density in 2010 . We made our choice of this threshold based on the entire distribution of retail property density and our various experiments. Changing the threshold of density is part of our sensitivity analysis.
} 
gives more details about how we construct shopping districts. Figure 1 shows the constructed inner-city shopping district of Groningen in 2011 as an example.

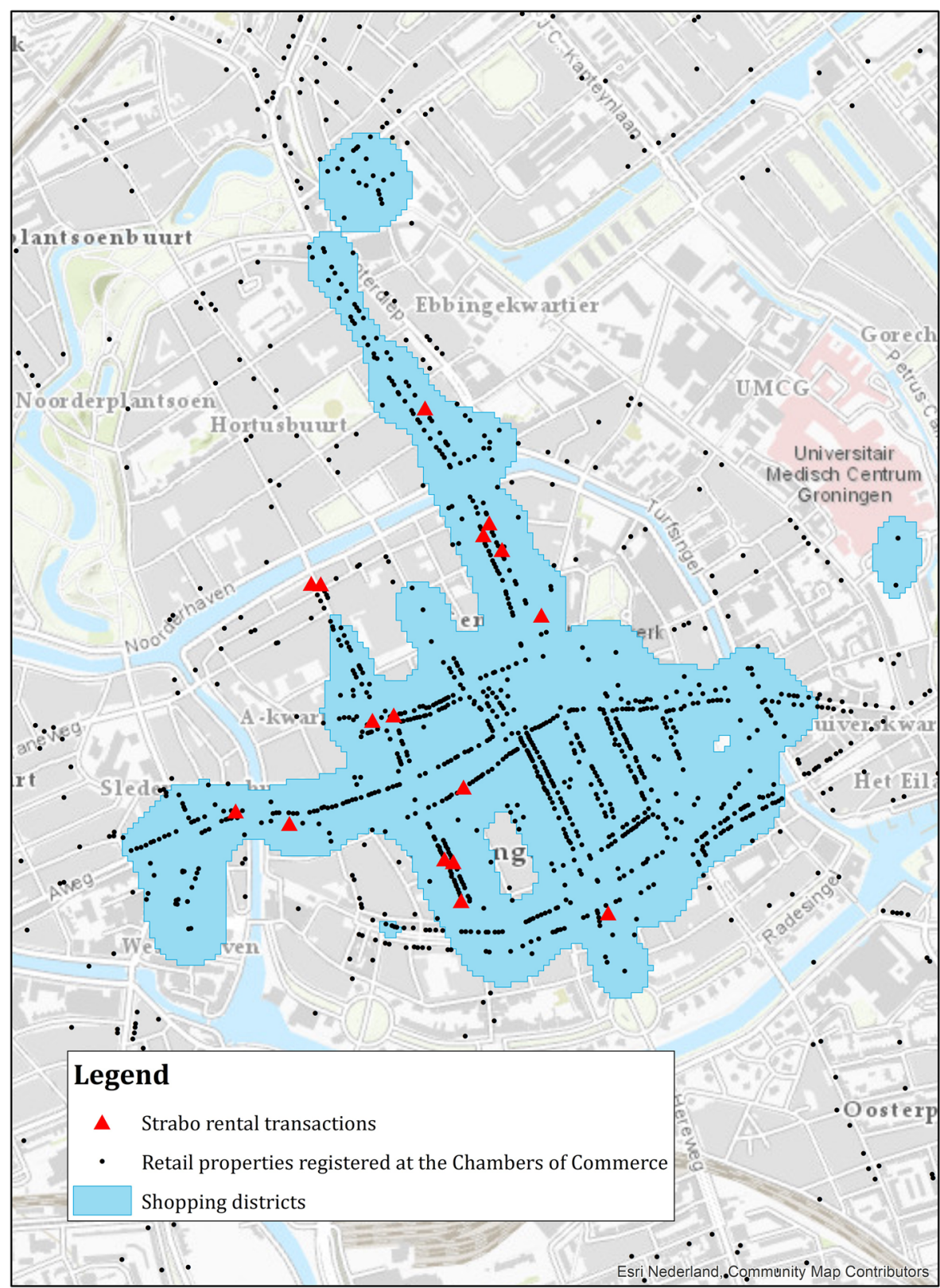

Fig. 1 An example of shopping districts constructed based on retail property densities. This figure shows the inner-city shopping district in the city of Groningen in 2011. The blue area represents the shopping district. The black dots depict registered retail properties in 2011 and the red triangles are rental transactions in 2011 
Table 1 Summary statistics of shopping districts

\begin{tabular}{llllll}
\hline & Mean & Std.Dev. & Median & Min & Max \\
\hline Shopping district size (in 1,000 $\mathrm{m}^{2}$ ) & 120.240 & 153.390 & 81.5 & 0.8 & $1,824.9$ \\
Number of retail properties in a & 193.745 & 273.281 & 110 & 2 & 3,235 \\
$\quad$ shopping district & & & & 11 & 23,295 \\
Number of jobs in a shopping district & $1,365.897$ & $2,053.798$ & 761 & 1.410 & 40.806 \\
$M I X$ & 22.206 & 7.540 & 23.442 & & \\
Number of shopping districts & 2,672 & & & & \\
\hline
\end{tabular}

Note: This table presents the summary statistics of shopping districts with at least one rental transaction observed. For each shopping district, we calculate its tenant mix, size, number of retail properties and number of jobs. To be precise, the tenant mix is calculated based on 5-digit SBI sector classification.

After the construction of shopping districts for every year, we calculate the size, number of retail properties and number of jobs for each shopping district. Table 1 presents the summary statistics of constructed shopping districts, where at least one rental transaction is observed. The size of these shopping districts ranges from 800 $\mathrm{m}^{2}$ to $1,824,900 \mathrm{~m}^{2}$, with a median of $81,500 \mathrm{~m}^{2}$. A shopping district contains on average about 194 shops and 1,366 jobs. The minimum number of shops in a shopping district is 2 , while the maximum is 3,235. Correspondingly, there are at least 11 jobs and at most 23,295 jobs in a shopping district. This indicates that we capture local neighborhood convenience shopping districts as well as city center shopping districts. ${ }^{8}$ Additional discussion about the shopping districts can be found in Appendix B.

\section{Tenant Mix}

The focus of our paper is the relationship between tenant mix and rents in shopping districts. To measure the tenant mix of a shopping district, we rely on the SBI sector classification contained in our granular data. The SBI sector classification code is composed of 2 to 5 digits. Each SBI code represents one classification of retail activity. Fewer digits signifies a more abstract way of classification. The 5-digit SBI code, which is the most detailed classification, is used in our analysis. ${ }^{9}$ The tenant mix of a shopping district $j$ in year $\mathrm{t}$ is defined as follows:

$$
M I X_{j t}=\frac{1}{\sum_{l=1}^{m}\left(\frac{B_{l j t}}{B_{j t}}\right)^{2}},
$$

\footnotetext{
${ }^{8}$ For a retail industry classification for shopping districts, see https://locatus.com/wp-content/uploads/ 2016/07/Shopping-area-classification.pdf

${ }^{9} \mathrm{We}$ also experiment to calculate the tenant mix using 3-digit and 4-digit SBI sector classification codes and apply them in the next empirical analysis. The results are similar and our main conclusion remains unchanged.
} 
where $B_{l j t}$ is the number of retail properties of SBI sector classification $l$ in shopping district $j$ in year $\mathrm{t}$ and $B_{j t}$ is the total number of retail properties in shopping district $j$ in year $\mathrm{t} ; m$ is the number of SBI sector classifications in shopping district $j$ in year t. Our tenant mix is actually the reciprocal of the well-known Herfindahl Index. ${ }^{10}$ Note that $M I X_{j t}$ cannot be smaller than 1 . When $M I X_{j t}$ equals 1 , it means all retail properties in shopping district $j$ are of the same SBI sector classification. $M I X_{j t}$ increases when retail activities in shopping district $j$ become more diverse. Table 1 shows that the mean of $M I X_{j t}$ is 22.206 , the median is 23.442 and the standard deviation is 7.540 for the shopping districts in which we observe at least one rental transaction. The maximum of $M I X_{j t}$ is 40.806 , which represents the most diverse shopping district. The minimum of $M I X_{j t}$ is 1.410 , which means almost no diversity.

\section{Retail Rents}

Our dataset of retail rents comes from Strabo, a consulting firm that conducts market research and collects commercial property data. The Strabo dataset contains 9,436 rental transactions for the Dutch retail market from 1996 to 2011. It provides detailed information about rental transactions, including annual rent, property size, precise location, name of the tenant and year of transaction. We use the precise location to map rental transactions to the all-parcel file. The all-parcel file, Administration of Buildings and Addresses (BAG) dataset, provides information on the building year and geo-location of every building in the Netherlands. Based on geo-location, we then match all rental transactions with the shopping districts in the corresponding year. There are 6,864 rental transactions that are located in a shopping district at the time of being transacted. So for each rental transaction incorporated in a shopping district, we have detailed information on their retail rents, property characteristics, and corresponding shopping district characteristics, all measured at the year when the rental transaction happened. Figure 2 maps the location of retail properties registered at the Dutch Chamber of Commerce and rental transactions by taking year 2011 as an example. Black dots represent all retail properties registered at the Dutch Chambers of Commerce in 2011 and red triangles represent all rental transactions in $2011 .{ }^{11}$

Table 2 presents summary statistics for rental transactions located in a shopping district. The average annual rent for a retail property is about 50,071 euros. The average annual rent per $m^{2}$ is about 291 euros. Annual rents vary between 15 and 2,351 euros per $m^{2}$. Most retail properties with the lowest rents per $m^{2}$ refer to retail properties in small cities and transacted in the late 1990s. Retail properties with the highest rent per $m^{2}$ are usually located in very popular streets, such as Kalverstraat in Amsterdam. Since rental transactions are matched with shopping districts, we gain tenant mix for every rental transaction. The mean of the tenant mix is 22.368 and the standard error is 6.077 .

\footnotetext{
${ }^{10}$ The Herfindahl Index has been previously used to measure tenant mix. See, e.g., Des Rosiers et al. (2009) and Ambrose et al. (2016).

${ }^{11}$ For further details about data management, see Appendix B.
} 


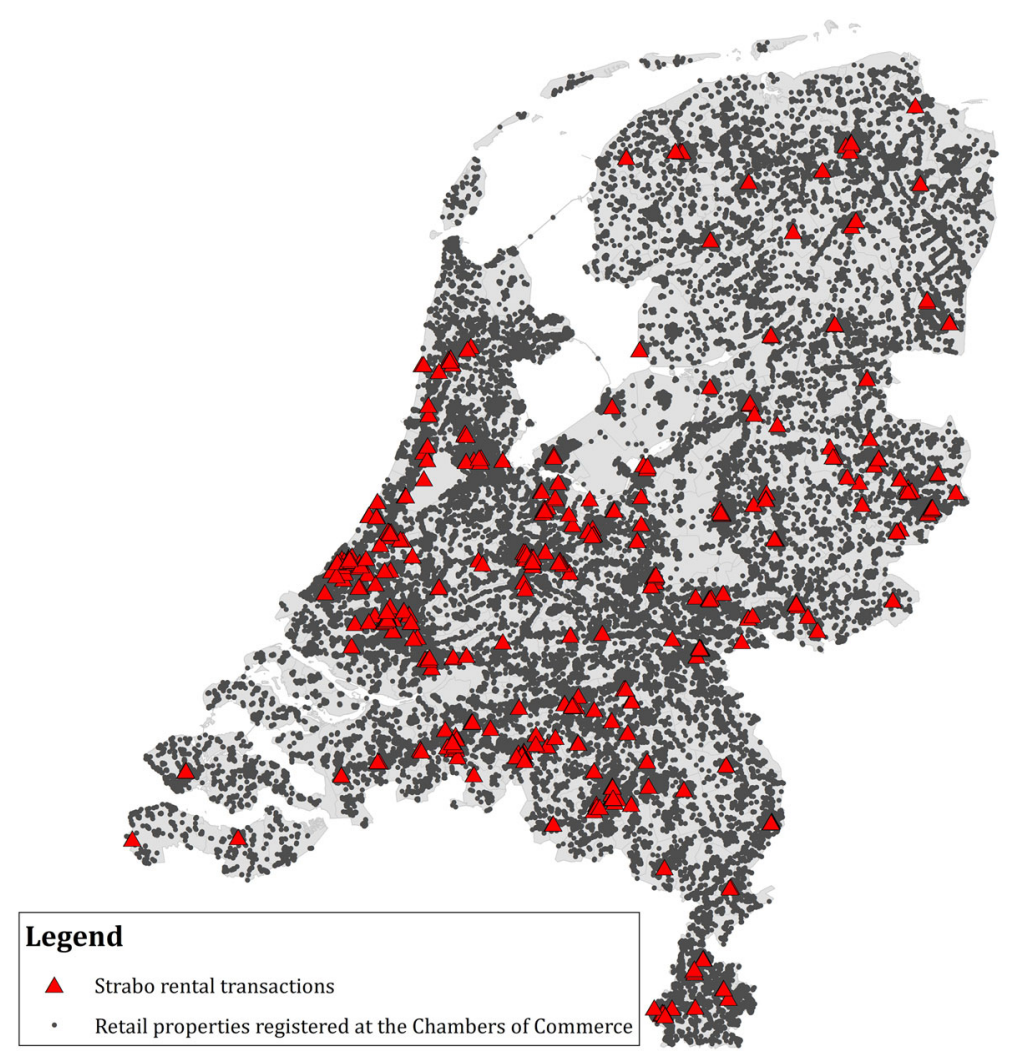

Fig. 2 Location of retail properties and rental transactions in the Netherlands, 2011. This figure shows the location of retail properties registered at the Dutch Chamber of Commerce and rental transactions, taking year 2011 as an example. Black dots represent all retail properties registered at the Dutch Chambers of Commerce in 2011 and red triangles represent all rental transactions in 2011

Table 2 provides also information on structural characteristics of these retail properties. The average size of 226 square meters reflects the small size of many high street retail properties in the Netherlands. About $40 \%$ of the tenants of rental transactions belong to a retail chain. ${ }^{12}$ About $21 \%$ of the rental transactions refer to retail properties located in inner-city shopping malls relative to street shops. ${ }^{13}$ About $18 \%$ of the retail properties are located at the corner of a street. ${ }^{14} \mathrm{We}$ also compute the distance between a retail property to the nearest train station, as well as the distance between it and the nearest water body. The average distance to the nearest train station is about 1,872 meters, and the average distance to the nearest water body is about 225

\footnotetext{
${ }^{12}$ For any retail tenants who rent and operate at multiple retail properties, we define them as a retail chain. It can refer to not just shops but also restaurants or any other types of retail tenants.

${ }^{13}$ In the Netherlands, shopping malls are usually located on high streets in cities, which means many shopping malls are contained in shopping districts. For an example, see Shopping Centre Magna Plaza Amsterdam. https://www.magnaplaza.nl/.

${ }^{14} \mathrm{We}$ set Corner $=1$ if a retail property is located within 15 meters of an interaction of streets.
} 
Table 2 Summary statistics of rental transactions

\begin{tabular}{|c|c|c|c|c|c|}
\hline & Mean & Std. Dev. & Median & Min & Max \\
\hline Rent price & $50,070.950$ & $40,933.820$ & 36,529 & 9,000 & 338,380 \\
\hline Rent price per $m^{2}$ & 291.408 & 201.164 & 238 & 15 & 2,351 \\
\hline $\operatorname{MIX}$ & 22.368 & 6.077 & 22.798 & 1.410 & 40.806 \\
\hline Property size $\left(m^{2}\right)$ & 225.527 & 248.462 & 155 & 20 & 4,200 \\
\hline Transaction year & 2003.627 & 4.428 & 2004 & 1996 & 2011 \\
\hline $\begin{array}{l}\text { Average income per resident } \\
\text { (in } 1,000 \text { euros) }\end{array}$ & 15.690 & 5.610 & 14 & 0 & 43.6 \\
\hline Population density per $\mathrm{km}^{2}$ & $6,036.453$ & $3,501.559$ & 5,419 & 2 & 28,060 \\
\hline Distance to train station $(m)$ & $1,872.436$ & $3,038.740$ & 846.038 & 27.268 & $22,766.360$ \\
\hline Distance to water body $(m)$ & 225.362 & 169.818 & 184.647 & 2.265 & $1,180.464$ \\
\hline Chain (1=yes) & 0.396 & & & & \\
\hline Corner (1=yes) & 0.179 & & & & \\
\hline $\begin{array}{l}\text { Located in a shopping mall } \\
\text { (1=yes) }\end{array}$ & 0.212 & & & & \\
\hline \multicolumn{6}{|l|}{ Building status } \\
\hline Existing (1=yes) & 0.933 & & & & \\
\hline New (1=yes) & 0.049 & & & & \\
\hline Renovated (1=yes) & 0.018 & & & & \\
\hline \multicolumn{6}{|l|}{ Building periods } \\
\hline$<1945$ & 0.422 & & & & \\
\hline $1945-1960$ & 0.100 & & & & \\
\hline $1961-1970$ & 0.049 & & & & \\
\hline $1971-1980$ & 0.069 & & & & \\
\hline $1981-1990$ & 0.050 & & & & \\
\hline $1991-2000$ & 0.108 & & & & \\
\hline$>2000$ & 0.203 & & & & \\
\hline Number of rental transactions & 6,864 & & & & \\
\hline
\end{tabular}

Note: Table 2 presents summary statistics for rental transactions located in a shopping district when they are transacted. Distance to train station and to water body is computed using GIS techniques. Chain $=1$ if any retail tenants rent and operate at multiple retail properties. Corner $=1$ if a retail property is located within 15 meters of an intersection of streets. Building period is obtained from BAG. Neighborhood characteristics are acquired from CBS neighborhood statistics.

meters. Furthermore, $4.9 \%$ of the properties are newly built when transacted, while $1.8 \%$ are just renovated. In total, $42 \%$ of the properties are built before $1945,38 \%$ between 1945 and 2000, and $20 \%$ after 2000. The distribution of building periods in our sample reflects the historical footprint of retail planning in the Netherlands.

We also gather information on neighborhood characteristics for our rental transactions by matching rental transactions with CBS neighborhood statistics. Neighborhood characteristics capture part of the location effects on retail rents. As we can see in Table 2, the average income per resident in the neighborhood is about 15,690 
euros annually. The average population density of the neighborhood is about 6,036 per $\mathrm{km}^{2}$.

\section{Empirical Model}

\section{Functional Form}

The aim of our paper is to investigate the relationship between tenant mix and rents. We start investigating the functional form with a standard hedonic price model where we include retail rents as the dependent variable and tenant mix as the independent key variable, controlling for other variables that may have an impact on retail rents. Let $R_{i j t}$ represent the rent of a retail property $i$ located at shopping district $j$ in year $t$. Our empirical model is formulated as follows:

$$
\ln \left(R_{i j t}\right)=\alpha+\beta M I X_{j t}+\theta C_{i t}+\phi X_{i t}+\gamma_{t}+\mu_{j}+\epsilon_{i j t},
$$

where $M I X_{j t}$ is the tenant mix of a shopping district $j$ in year $t$; $C_{i t}$ is a vector consisting of the number of retail properties in different SBI sector classifications within a buffer of property $i$ in year $t$; $X_{i t}$ is a vector of control variables of retail property $i$ in year $t$ which include property, shopping district and location characteristics; $\gamma_{t}$ and $\mu_{j}$ are year and location fixed effects; $\epsilon_{i t}$ is an i.i.d. error term; and $\alpha, \beta, \theta, \phi$, $\gamma_{t}$ and $\mu_{j}$ are the parameters to be estimated. $C_{i t}$ is used to capture the competition that a retail tenant faces in the proximity of the property. We assume the radius of the buffer that we used to calculate $C_{i t}$ to be 100 meters, since we think the competition effect is rather local. ${ }^{15}$

For retail property characteristics we include property size (in $\mathrm{m}^{2}$ ), building period, and an indicator for if the retail property is located in a shopping mall, as owners of shopping malls often for ask higher rents relative to street shops. We also include dummy variables indicating new or just renovated properties because if a property is newly built or has just been renovated, one expects a higher rent for its retail tenant. Furthermore, we include tenant-type controls to capture unobserved differences in retail tenants' behaviors.

Other important determinants of retail rents are location characteristics. First, we include the average income per resident and population density of the neighborhood that a retail property is in, since neighborhood status may impact retail rents. Second, we add the logarithm of the distance between a retail property and its nearest train station, as well as the distance to the nearest water body. If a retail property is close to a train station, it is more accessible to consumers. In the Netherlands, water bodies, such as canals, are hotspots which attract many tourists. The distance to a train station or a water body may have an impact on retail rents. We also include urbanity fixed

\footnotetext{
${ }^{15}$ We tested by changing the buffer radius to be 50 meter and 250 meters. We also tried to calculate the number of retail properties in each SBI sector classification for every shopping district, instead of buffers. None of these effected significant changes to our results.
} 
effects. ${ }^{16}$ Last, we include PC4 dummies to control for all time-invariant location characteristics. ${ }^{17}$

The standard hedonic price model as depicted in Eq. 2 has some important limitations. One such limitation is that it assumes a linear functional form between retail rents and tenant mix. However, a nonlinear relationship may actually exist between retail rents and tenant mix. ${ }^{18}$ Because retail rent is a function of numerous characteristics, including many location fixed effects, it would be a tedious task to estimate a fully nonparametric hedonic regression. We therefore propose to use a semiparametric model which does not assume a specific functional form between retail rents and tenant mix. Such a semiparametric model is argued to estimate the hedonic price model more accurately when there are enough data (Sheppard 1999). Similar semiparametric hedonic regression models can be found in the literature (see, e.g., Bajari and Kahn 2005; Bin 2005; Bontemps et al. 2008, Koster and Rouwendal 2012; Koster et al. 2014). The semiparametric model we propose is as follows:

$$
\ln \left(R_{i j t}\right)=\alpha+\Omega\left(M I X_{j t}\right)+\theta C_{i t}+\phi X_{i t}+\gamma_{t}+\mu_{j}+\epsilon_{i j t},
$$

where $\Omega$ (.) is a smooth function of tenant mix with a bounded first derivative. Following the method of Yatchew $(1997,1998)$, we use a differencing method to fit the model. We first sort the data from the smallest to the largest tenant mix. We then take the first difference of Eq. 3 and estimate the differenced model using OLS. ${ }^{19}$ These results will provide us with initial evidence of the functional form between retail rents and tenant mix.

\section{Unobserved Heterogeneity}

To further explore the relationship between tenant mix and rents, we investigate unobserved heterogeneity in rents. Whereas in the standard hedonic model we ignored retail properties outside shopping districts, we now include these observations to exploit variation in whether or not a retail property has ever been or will be included in a shopping district.

This addition is made possible by the large number of shopping districts in the Netherlands and access to information about the development of those shopping districts - in terms of boundary, shape and size - between 1996 and 2011. With the

\footnotetext{
${ }^{16}$ In the Netherlands, every neighborhood is given an urbanity class 1-5 based on its density of addresses. Class 1 represents very high urbanity, which represents more than 2500 addresses per $\mathrm{km}^{2}$. Class 5 represents no urbanity, which represents less than 500 addresses per $\mathrm{km}^{2}$.

${ }^{17}$ In the Netherlands, a postcode is a combination of four digits and two letters. The former part, 4 digits, is called PC4 and usually stands for a neighborhood.

${ }^{18}$ We estimated several different regressions to test for the nonlinear relationship between retail rents and tenant mix. To be specific, we estimated specifications where we included different polynomials. We also estimated a specification where we categorized the tenant mix instead of including the continuous tenant mix variable. The results of these different specifications suggest that the relationship between retail rents and tenant mix may be nonlinear, which gives us more reasons to consider nonparametric estimation methods. These regressions with different specifications can be found in Appendix C.

${ }^{19}$ We also tried different differencing orders for the semiparametric regression. The results we obtained are quite similar. However, considering using higher order differencing may lead to biased results, we prefer to use the first difference here.
} 
availability of such data, we are able to estimate a difference-in-difference model which allows us, contrary to the standard hedonic model, to control for pre-existing differences between retail properties located in shopping districts and those outside (see, e.g., Been et al. 2016; Van Duijn et al. 2016; Van der Vlist et al. 2019). The difference-in-difference model we propose is as follows:

$$
\begin{aligned}
\ln \left(R_{i j t}\right) & =\alpha+\tau_{1} S D_{i}+\tau_{2} S D_{i} * S_{i t}+\tau_{3} S D_{i} * S_{i t} * M I X_{j t} \\
& +\theta C_{i t}+\phi X_{i t}+\gamma_{t}+\mu_{j}+\epsilon_{i j t},
\end{aligned}
$$

where $S D_{i}$ is a dummy variable which equals to 1 if retail property $i$ has ever been or will be included in a shopping district; $S_{i t}$ is a dummy variable which equals to 1 if a retail property $i$ is located in a shopping district in its transaction year $t$.

The difference-in-difference model includes three key variables, $S D_{i}, S D_{i} * S_{i t}$ and $S D_{i} * S_{i t} * M I X_{j t}$. We use these variables to investigate the heterogeneity in retail rents. $S D_{i}$ captures the heterogeneity in retail rents between retail properties that are never and never will be in a shopping district and those that have been or will be in a shopping district but are, in transaction year $t$, not in a shopping district. $S D_{i} * S_{i t}$ captures the heterogeneity in retail rents between retail properties which have been or will be in a shopping district but are, in a transaction year $t$, not in a shopping district and retail properties which are in a shopping district in transaction year $t$, without considering the tenant mix of shopping districts. $S D_{i} * S_{i t} * M I X_{j t}$ allows the variation in tenant mix. It captures the heterogeneity in retail rents between retail properties which are, in transaction year $t$, located in shopping districts with different tenant mix. We let the data decide whether the heterogeneity in retail rents depends on the tenant mix of shopping districts. Although we now estimate tenant mix in a parametric fashion, the results provide us with additional evidence of the association between retail rents and tenant mix by accounting for unobserved heterogeneity.

\section{Results}

\section{Baseline Results}

Table 3 presents the results of our baseline models, i.e. Eqs.2 and 3. Column (1) is the linear regression excluding the number of retail properties of each SBI sector classification within 100 meters of a rental transaction. We add the number of retail properties of each classification in Column (2). ${ }^{20}$

As we can see, in Column (1), the coefficient of tenant mix is positive and significant, which implies a positive relationship between tenant mix and retail rents. In Column (2), where we control for competition of retail properties within 100 meters, the coefficient of tenant mix is still positive and significant but slightly lower. When the tenant mix of a shopping district increases by 1 unit, retail rents increase by $0.66 \%(=(\exp (0.00658)-1) * 100)$. Results from both specifications suggest that retail tenants pay higher rents in shopping districts with greater tenant mix.

\footnotetext{
${ }^{20}$ The number of retail properties of each classification are calculated based on 3-digit SBI code.
} 
Table 3 Baseline regression results

\begin{tabular}{|c|c|c|c|c|}
\hline & $\begin{array}{l}\text { (1) } \\
\text { Linear }\end{array}$ & $\begin{array}{l}\text { (2) } \\
\text { Linear }\end{array}$ & $\begin{array}{l}\text { (3) } \\
\text { Semiparametric }\end{array}$ & $\begin{array}{l}\text { (4) } \\
\text { Semiparametric }\end{array}$ \\
\hline$M I X$ & $\begin{array}{l}0.00880^{* * * *} \\
(0.00269)\end{array}$ & $\begin{array}{l}0.00658^{* *} \\
(0.00264)\end{array}$ & See Fig. 3 & See Fig. 3 \\
\hline Log of size & $\begin{array}{l}0.547 * * * \\
(0.0141)\end{array}$ & $\begin{array}{l}0.578 * * * \\
(0.0135)\end{array}$ & $\begin{array}{l}0.543 * * * \\
(0.0127)\end{array}$ & $\begin{array}{l}0.571 * * * \\
(0.0120)\end{array}$ \\
\hline Chain (1=yes) & $\begin{array}{l}0.123 \\
(0.0832)\end{array}$ & $\begin{array}{l}0.112 \\
(0.0791)\end{array}$ & $\begin{array}{l}0.130 \\
(0.0865)\end{array}$ & $\begin{array}{l}0.118 \\
(0.0815)\end{array}$ \\
\hline Log of size*Chain & $\begin{array}{l}0.0229 \\
(0.0161)\end{array}$ & $\begin{array}{l}0.0174 \\
(0.0151)\end{array}$ & $\begin{array}{l}0.0188 \\
(0.0166)\end{array}$ & $\begin{array}{l}0.0128 \\
(0.0157)\end{array}$ \\
\hline Corner (1=yes) & $\begin{array}{l}0.0191 \\
(0.0150)\end{array}$ & $\begin{array}{l}0.00868 \\
(0.0135)\end{array}$ & $\begin{array}{l}0.0123 \\
(0.0144)\end{array}$ & $\begin{array}{l}0.00430 \\
(0.0136)\end{array}$ \\
\hline $\begin{array}{l}\text { Located in a shopping } \\
\text { mall (1=yes) }\end{array}$ & $\begin{array}{l}0.0841 * * * \\
(0.0210)\end{array}$ & $\begin{array}{l}0.0644 * * * \\
(0.0232)\end{array}$ & $\begin{array}{l}0.0718^{* * *} \\
(0.0207)\end{array}$ & $\begin{array}{l}0.0616^{* * *} \\
(0.0195)\end{array}$ \\
\hline $\begin{array}{l}\text { Shopping district size } \\
\text { (in } 1,000 \mathrm{~m}^{2} \text { ) }\end{array}$ & $\begin{array}{l}0.000267^{* *} \\
(0.000120)\end{array}$ & $\begin{array}{l}0.000198 * \\
(0.000101)\end{array}$ & $\begin{array}{l}0.000403^{* * *} \\
(0.000102)\end{array}$ & $\begin{array}{l}0.000267 * * * \\
(9.65 \mathrm{e}-05)\end{array}$ \\
\hline $\begin{array}{l}\text { Average income per resident } \\
\text { (in 1,000 euros) }\end{array}$ & $\begin{array}{l}-0.00213 \\
(0.00435)\end{array}$ & $\begin{array}{l}0.000128 \\
(0.00390)\end{array}$ & $\begin{array}{l}0.00167 \\
(0.00412)\end{array}$ & $\begin{array}{l}0.00371 \\
(0.00394)\end{array}$ \\
\hline Population density per $\mathrm{km}^{2}$ & $\begin{array}{l}-1.64 \mathrm{e}-05^{* * * *} \\
(4.48 \mathrm{e}-06)\end{array}$ & $\begin{array}{l}-1.23 \mathrm{e}-05^{* * *} \\
(4.44 \mathrm{e}-06)\end{array}$ & $\begin{array}{l}-1.14 \mathrm{e}-05^{* * *} \\
(4.36 \mathrm{e}-06)\end{array}$ & $\begin{array}{l}-8.75 \mathrm{e}-06^{* *} \\
(4.14 \mathrm{e}-06)\end{array}$ \\
\hline Log of distance to train station & $\begin{array}{l}0.0325 \\
(0.0580)\end{array}$ & $\begin{array}{l}0.00344 \\
(0.0421)\end{array}$ & $\begin{array}{l}0.0205 \\
(0.0241)\end{array}$ & $\begin{array}{l}-0.0113 \\
(0.0231)\end{array}$ \\
\hline Log of distance to water body & $\begin{array}{l}0.0492 * * * \\
(0.0172)\end{array}$ & $\begin{array}{l}0.0331 * * \\
(0.0132)\end{array}$ & $\begin{array}{l}0.0605^{* * * *} \\
(0.0110)\end{array}$ & $\begin{array}{l}0.0354^{* * * *} \\
(0.0105)\end{array}$ \\
\hline New (1=yes) & $\begin{array}{l}0.102 * * \\
(0.0407)\end{array}$ & $\begin{array}{l}0.153 * * * \\
(0.0426)\end{array}$ & $\begin{array}{l}0.0435 \\
(0.0381)\end{array}$ & $\begin{array}{l}0.0798 * * \\
(0.0361)\end{array}$ \\
\hline Renovated ( $1=$ yes) & $\begin{array}{l}0.107^{* * * *} \\
(0.0400)\end{array}$ & $\begin{array}{l}0.150^{* * *} \\
(0.0442)\end{array}$ & $\begin{array}{l}0.117 * * \\
(0.0461)\end{array}$ & $\begin{array}{l}0.159^{* * * *} \\
(0.0435)\end{array}$ \\
\hline SBI sector classification & no & yes & no & yes \\
\hline Building periods & yes & yes & yes & yes \\
\hline Transaction year fixed effects & yes & yes & yes & yes \\
\hline Tenant category fixed effects & yes & yes & yes & yes \\
\hline Urbanity fixed effects & yes & yes & yes & yes \\
\hline PC4 fixed effects & yes & yes & yes & yes \\
\hline Observations & 6,864 & 6,864 & 6,863 & 6,863 \\
\hline Adjusted $R^{2}$ & 0.654 & 0.695 & 0.571 & 0.620 \\
\hline
\end{tabular}

Note: Dependent variable is $\log$ of retail rent. Column (1) and (2) shows results of the linear hedonic model, while Column (3) and (4) show results from the semiparametric regression. SBI sector classifications in the table stand for the number of retail properties of each classification within 100 meters of a rental transaction. Estimates of the function of MIX from Column (3) and (4) are graphed in Fig. 3. Clustered standard errors at PC4 level in parentheses. ${ }^{* * *} p<0.01,{ }^{* *} p<0.05,{ }^{*} p<0.1$ 
The coefficients of control variables show expected signs. Using results of Column (2) for analysis, we see that the rent of a retail property located in a shopping mall will be about $6.65 \%$ higher than a retail property on the high street. Retail rents for newly built and renovated properties will be $16.53 \%$ and $16.18 \%$ higher respectively than an existing and unchanged property. The size of a shopping district also has a positive relationship with retail rents. It captures a part of the agglomeration effects of retail properties as we also control for the number of retail properties of each SBI sector classification within 100 meters. As for neighborhood characteristics, when the neighborhood's average income increases, retail rents will be higher, although this effect is not significant. There is, however, a negative and significant relationship between population density and retail rents. This is because population density measures the density of residents in the neighborhood. When population density is high, it means this neighborhood is mainly a residential area, not a highly dense shopping district. Retail properties located in a residential area usually have lower rents. The other control variables also have expected coefficients, but they are not significant.

Columns (3) and (4) show results of the semiparametric regressions. If we compare them with Column (1) and (2), we can see the control variables have quite similar coefficients. The similar coefficients of control variables mean that the regression results of the semiparametric model are consistent. Contrary to linear regression, semiparametric regression does not estimate the coefficient of tenant mix. Instead, it outputs a smoothed graph of function $\Omega\left(M I X_{j t}\right)$. Figure 3 illustrates the functional form of the $\log$ of rent (y-axis) and tenant mix (x-axis) based on the semiparametric regression results shown in Columns (3) and (4) of Table 3. The blue dashed and red solid curves represent the functional forms based on Columns (3) and (4) respectively. In addition, we plot the histogram of tenant mix to show its distribution. It can be observed that the curves are steepest - where the marginal effects of tenant mix on retail rents are the highest (about $1.4 \%$ ) - at the bulk of the distribution.

We can conclude from Fig. 3 that, in general, tenant mix has a positive relationship with retail rents. Taking the red solid curve as an example, when tenant mix increases from 1 to $12, \log$ of rent increases gradually from 10.44 to 10.49 . For tenant mix between 12 and 30, log of rent soars from 10.49 to about 10.64 with a much steeper slope. For both intervals, we can observe an obvious positive relationship between tenant mix and retail rents. After tenant mix exceeds 30, the slope of the curve is almost flat. ${ }^{21}$ This means that when tenant mix surpasses a certain level, an increase of tenant mix will not bring much increment in retail rents. It is apparent that the bulk of our observations have a tenant mix between 18 and 30. This means that, for the majority of our observations, retail rents have a clear and substantial positive relationship with tenant mix. When tenant mix is smaller than 20, the curve of Column (4) shows a higher return of $\log$ of rent with respect to tenant mix, compared to the curve of Column (3). When tenant mix is larger than 33, the curve of Column (3) shows a downward slope, which means now retail rents decrease with the increment of tenant

\footnotetext{
${ }^{21}$ These results are quite similar as our findings using categorized tenant mix, as shown in Column (2) of Table 7 in Appendix C.
} 


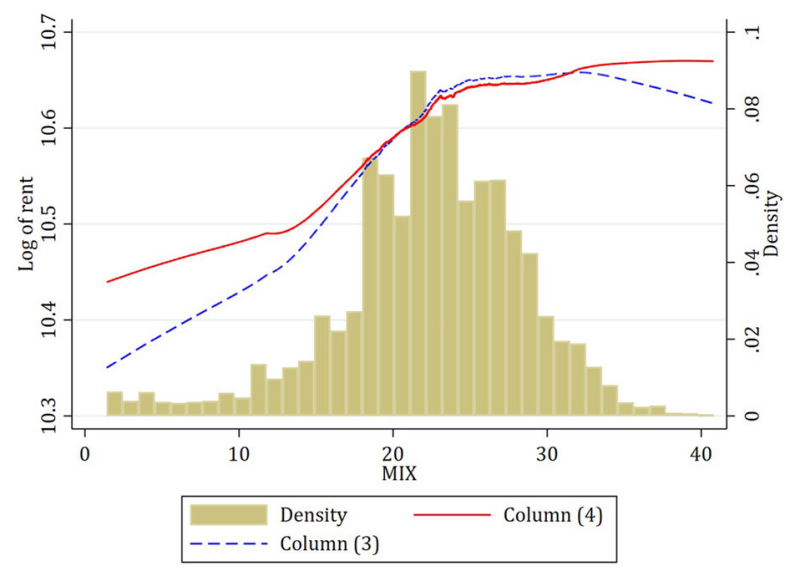

Fig. 3 Functional form of tenant mix on retail rents based on semiparametric regression. This figure shows estimates of the function $\Omega\left(M I X_{j t}\right)$ with respect to tenant mix. The blue dashed curve represents the estimates from Column (3) of Table 3, while the red solid curve represents that of Column (4) of Table 3. Both curves together show a positive relationship between tenant mix and retail rents. This especially holds when tenant mix is smaller than 30 . This graph also illustrates the nonlinearity of the relationship between tenant mix and retail rents

mix. This is because when tenant mix is too high, competition between retail tenants dominates the market instead of positive externalities, which counteracts the positive effect of tenant mix. It can be seen that after including number of retail properties in each SBI sector classification in Column (4), this downward slope does not exist anymore.

The semiparametric regression confirms our conclusion from the linear regression that tenant mix has a positive relationship with retail rents in shopping districts. Furthermore, it does not specify a particular function form for retail rents and tenant mix, which allows us to describe their relationship in more detail and more accurately. When tenant mix is smaller than 30 , we can observe an obvious and substantial positive relationship between tenant mix and retail rents. When tenant mix is higher than 30 , this slope of the tenant mix becomes almost flat.

\section{Results from the Difference-in-Difference Model}

Table 4 presents the results of Eq. 4, the difference-in-difference model. As the aim of this model is to exploit the heterogeneity in retail rents between retail properties which have been or will be in a shopping district but are, in a transaction year $t$, not in a shopping district and retail properties which are in a shopping district in transaction year $t$. To facilitate this, we use all available rental transactions in the Netherlands, as opposed to the baseline model, which uses only rental transactions located in a shopping district when transacted. However, to control for potential endogeneity, for retail properties that have ever been or will be included in a shopping district, we use 
Table 4 Difference-in-difference regression results

\begin{tabular}{|c|c|c|c|}
\hline & $\begin{array}{l}\text { (1) } \\
\text { Average Effect }\end{array}$ & $\begin{array}{l}\text { (2) } \\
\text { Interacted with } \\
\text { Tenant mix }\end{array}$ & $\begin{array}{l}\text { (3) } \\
\text { Interacted with } \\
\text { Tenant mix }\end{array}$ \\
\hline$S D$ & $\begin{array}{l}0.0831 * * * \\
(0.0256)\end{array}$ & $\begin{array}{l}0.0845^{* * *} * \\
(0.0256)\end{array}$ & $\begin{array}{l}0.0829 * * * \\
(0.0247)\end{array}$ \\
\hline $\mathrm{SD} * \mathrm{~S}$ & $\begin{array}{l}0.155 * * * \\
(0.0295)\end{array}$ & $\begin{array}{l}-0.00185 \\
(0.0495)\end{array}$ & $\begin{array}{l}-0.0218 \\
(0.0421)\end{array}$ \\
\hline $\mathrm{SD} * \mathrm{~S} * \mathrm{MIX}$ & & $\begin{array}{l}0.00762 * * * \\
(0.00207)\end{array}$ & $\begin{array}{l}0.00336^{*} \\
(0.00185)\end{array}$ \\
\hline Log of size & $\begin{array}{l}0.594 * * * \\
(0.0132)\end{array}$ & $\begin{array}{l}0.596 * * * \\
(0.0134)\end{array}$ & $\begin{array}{l}0.621 * * * \\
(0.0121)\end{array}$ \\
\hline Chain (1=yes) & $\begin{array}{l}0.357 * * * \\
(0.0687)\end{array}$ & $\begin{array}{l}0.343 * * * \\
(0.0688)\end{array}$ & $\begin{array}{l}0.257 * * * \\
(0.0635)\end{array}$ \\
\hline Log of size*Chain & $\begin{array}{l}-0.0240^{* *} \\
(0.0121)\end{array}$ & $\begin{array}{l}-0.0217 * \\
(0.0121)\end{array}$ & $\begin{array}{l}-0.0127 \\
(0.0113)\end{array}$ \\
\hline Corner (1=yes) & $\begin{array}{l}0.0285^{*} \\
(0.0150)\end{array}$ & $\begin{array}{l}0.0271 * \\
(0.0149)\end{array}$ & $\begin{array}{l}0.00865 \\
(0.0128)\end{array}$ \\
\hline Located in a shopping mall (1=yes) & $\begin{array}{l}0.0937 * * * \\
(0.0199)\end{array}$ & $\begin{array}{l}0.0971 * * * \\
(0.0196)\end{array}$ & $\begin{array}{l}0.0923 * * * \\
(0.0195)\end{array}$ \\
\hline Average income per resident (in 1,000 euros) & $\begin{array}{l}0.00316 \\
(0.00304)\end{array}$ & $\begin{array}{l}0.00278 \\
(0.00307)\end{array}$ & $\begin{array}{l}0.00450 \\
(0.00281)\end{array}$ \\
\hline Population density per $\mathrm{km}^{2}$ & $\begin{array}{l}-1.37 \mathrm{e}-05^{* *} \\
(5.32 \mathrm{e}-06)\end{array}$ & $\begin{array}{l}-1.40 \mathrm{e}-05^{* * *} \\
(5.28 \mathrm{e}-06)\end{array}$ & $\begin{array}{l}-8.66 \mathrm{e}-06 * * \\
(4.14 \mathrm{e}-06)\end{array}$ \\
\hline Log of distance to train station & $\begin{array}{l}-0.0482 \\
(0.0445)\end{array}$ & $\begin{array}{l}-0.0526 \\
(0.0448)\end{array}$ & $\begin{array}{l}-0.0597 * \\
(0.0312)\end{array}$ \\
\hline Log of distance to water body & $\begin{array}{l}0.0449 * * \\
(0.0176)\end{array}$ & $\begin{array}{l}0.0436 * * \\
(0.0174)\end{array}$ & $\begin{array}{l}0.0262 * \\
(0.0142)\end{array}$ \\
\hline New (1=yes) & $\begin{array}{l}0.129 * * * \\
(0.0355)\end{array}$ & $\begin{array}{l}0.134 * * * \\
(0.0353)\end{array}$ & $\begin{array}{l}0.157 * * * \\
(0.0358)\end{array}$ \\
\hline Renovated (1=yes) & $\begin{array}{l}0.130 * * \\
(0.0561)\end{array}$ & $\begin{array}{l}0.136^{* *} \\
(0.0560)\end{array}$ & $\begin{array}{l}0.184 * * * \\
(0.0628)\end{array}$ \\
\hline SBI sector classification & no & no & yes \\
\hline Building periods & yes & yes & yes \\
\hline Transaction year fixed effects & yes & yes & yes \\
\hline Tenant category fixed effects & yes & yes & yes \\
\hline Urbanity fixed effects & yes & yes & yes \\
\hline PC4 fixed effects & yes & yes & yes \\
\hline Observations & 7,963 & 7,963 & 7,963 \\
\hline Adjusted $R^{2}$ & 0.695 & 0.697 & 0.734 \\
\hline
\end{tabular}

Note: Dependent variable is log of retail rent. This table shows the results of the difference-in-difference model. 7,963 observations are used in the regression, including those that have ever been or will be included in a shopping district and those that are never included in a shopping district. In Column (3), we add the number of retail properties within 100 meters of a rental transaction of each SBI sector classification. Clustered standard errors at PC4 level in parentheses. ${ }^{* * *} p<0.01,{ }^{* *} p<0.05,{ }^{*} p<0.1$ 
only those that are built before the shopping district is formed. As a result, a total of 7,963 rental transactions are used in the difference-in-difference analysis. ${ }^{22}$

Column (1) of Table 4 shows the results of the difference-in-difference hedonic regression model. $S D$ captures the heterogeneity in retail rents between retail properties that have ever been or will be included in a shopping district but, in transaction year $t$, are not in a shopping district and retail properties that are never included in a shopping district between 1996 and 2011. $S D_{i} * S_{i t}$ captures the heterogeneity in retail rents between retail properties which are, in transaction year $t$, located in a shopping district and retail properties which have ever been or will be included in a shopping district between 1996 and 2011 but are, in transaction year $t$, not in a shopping district, without considering tenant mix. In Column (2) we add the interaction of $S D_{i} * S_{i t}$ and $M I X_{j t}$, which captures the heterogeneity in retail rents between retail properties that are both in shopping districts, in transaction year $t$, but with different tenant mix. In Column (3) we add the number of retail properties within 100 meters of a rental transaction of each SBI sector classification.

In Column (1) we see that the rent of a retail property that has ever been or will be included in a shopping district but, in transaction year $t$, is not in a shopping district will be about $8.67 \%$ higher than a retail property that is never included in a shopping district between 1996 and 2011. The effect of being included in a shopping district when transacted is on average $16.77 \%$ if the heterogeneity in tenant mix of the various shopping districts is disregarded. In Column (2), we add the interaction of $S D_{i} * S_{i t}$ and $M I X_{j t}$. The results show that the heterogeneity in retail rents are largely explained by the variation in the tenant mix of shopping districts. This means that the heterogeneity in retail rents varies with the tenant mix of shopping districts. For example, the rent of a retail property in a shopping district, when transacted, with a tenant mix of 21 is about $0.89 \%$ higher than the rent of a retail property in a shopping district with a tenant mix of 20. Unsurprisingly, this varying heterogeneity becomes smaller in Column (3), as the number of retail properties of each SBI sector classification absorbs the competition effect from tenant mix (cf. Table 3). Using the results from Column (3), we can compute that the rent difference between retail properties in shopping districts with tenant mixes of 20 and 21 respectively is about $0.36 \%$.

Based on these results, we observe a large heterogeneity in retail rents which depends on being included in a shopping district or not. In addition, the heterogeneity in retail rents depends, to a small degree at least, on the tenant mix of the shopping district.

\section{Sensitivity Analysis}

To check the robustness of our results, we run a series of different sensitivity checks. First, we estimate models based on shopping districts delineated using different

\footnotetext{
${ }^{22}$ Table 8 of Appendix D presents descriptive statistics of observations used in the difference-in-difference analysis.
} 
thresholds. Second, we use some other diversity indices to replace the tenant mix used in our baseline model to see if different choices of indices will have any influences on our results.

\section{Different Thresholds for Shopping Districts}

We state above that one key element when delineating shopping districts is the choice of threshold. Different choices of thresholds result in different boundaries, shapes and sizes of shopping districts. It is evident that the tenant mix of a shopping district is sensitive to the delineation of the shopping district. We explore whether the choice of density threshold affects the relationship between retail rents and tenant mix.

We reconstruct two sets of shopping districts by choosing the thresholds of density to be the 75 th and 85 th percentiles of the retail property density. ${ }^{23}$ As the thresholds become higher, the constructed shopping districts shrink compared with shopping districts that we use in our baseline regression. As a consequence, the number of rental transactions that fall into a shopping district declines.

Table 5 reports the regression results using shopping districts constructed based on the 75th and 85th percentile in Columns (1) and (2), respecitvely. The number of observations - retail properties in shopping districts - are 5,600 and 3,746, respectively. ${ }^{24}$ Results in both columns show positive coefficients, which confirms the positive relationship between retail rents and tenant mix. This implies that the conclusion based on our main results remains the same. However, compared with our baseline results, the effect of tenant mix on retail rents becomes smaller. When MIX increases by 1 unit, retail rents increase by $0.49 \%$ and $0.40 \%$ in columns (1) and (2), respectively.

\section{Alternative Tenant Mix Indices}

In our baseline models, we calculate the tenant mix by using the formulation of the Herfindahl Index and the number of retail properties in each SBI sector classification. It is reasonable to argue that the positive effect of tenant mix is the result of choosing this particular type of diversity index. Therefore, we check its robustness by using two other well-known indices.

According to Eq. 1, the Herfindahl Index gives weight to SBI sector classifications that account for a large proportion in a shopping district. It is sensitive to the concentration level of shopping districts. To compensate for this effect, we compute an

\footnotetext{
${ }^{23}$ More explicitly, the involved density thresholds are respectively 6,148 jobs per $\mathrm{km}^{2}$ and 10,201 jobs per $\mathrm{km}^{2}$.

${ }^{24}$ Another consequence is, when we use the 85 th percentile to construct shopping districts, many shopping districts we get are as small as (if not smaller than) a PC4 area. This makes us to use city fixed effects instead of PC4 fixed effects in Column (2). Because if we continue to use PC4 to control for location fixed effects, the effect of tenant mix will be absorbed by the fixed effects such that the coefficient of tenant mix becomes small and insignificant.
} 
Table 5 Regression results with different thresholds

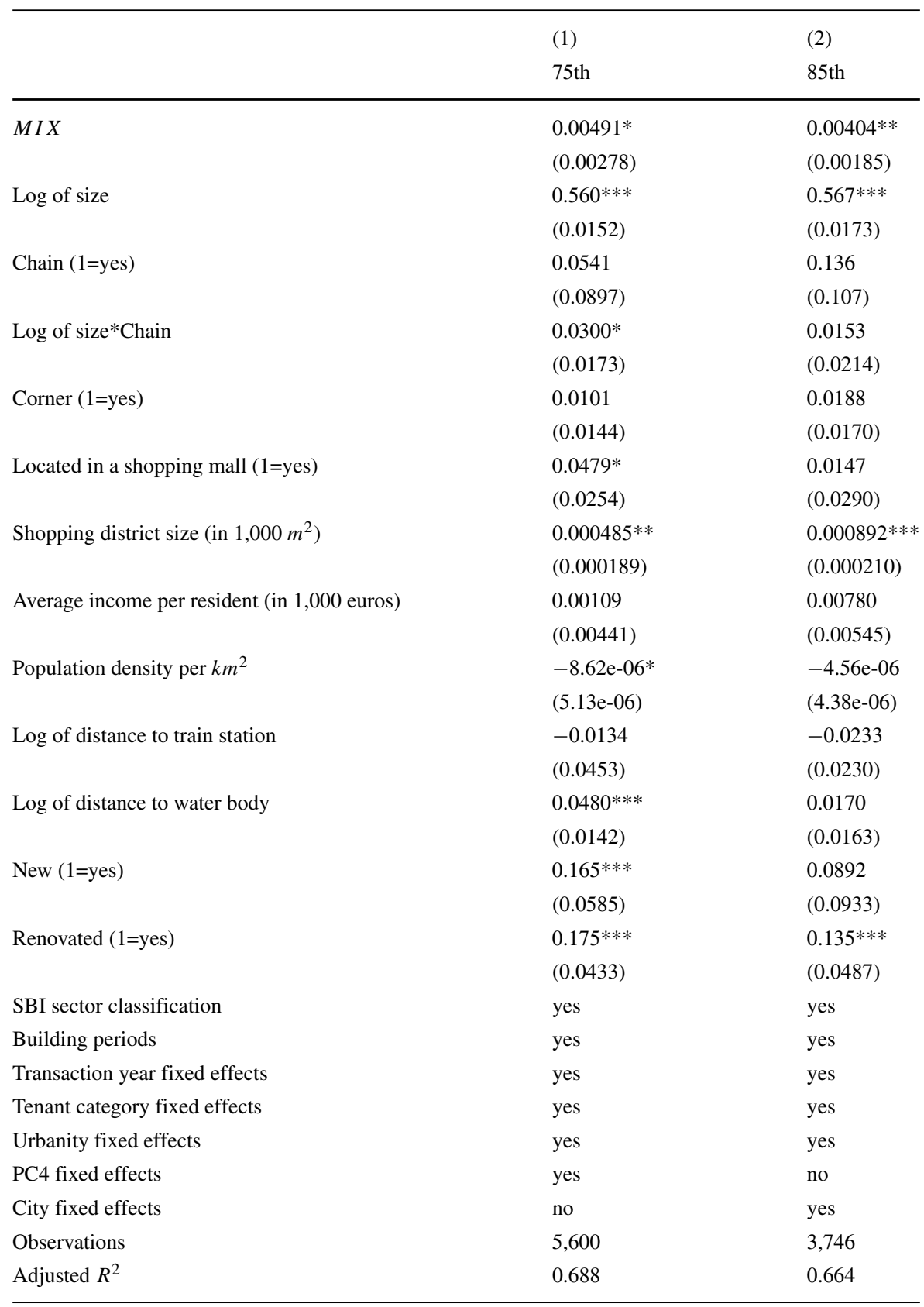

Note: Dependent variable is log of rent price. This table show results for shopping districts delineated based on different thresholds. Since the threshold is higher than the one used in the baseline model, shopping districts used in this table are fewer and smaller in size. As a result, fewer observations are used in both columns. Clustered standard errors at PC4 level in parentheses. ${ }^{* *} p<0.01,{ }^{* *} p<0.05,{ }^{*} p<0.1$ 
Table 6 Regression results with different diversity indices

\begin{tabular}{|c|c|c|}
\hline & $\begin{array}{l}\text { (1) } \\
\text { Shannon }\end{array}$ & $\begin{array}{l}\text { (2) } \\
\text { Weighted Herfindahl Index }\end{array}$ \\
\hline$M I X$ & $\begin{array}{l}0.0846^{* *} \\
(0.0331)\end{array}$ & $\begin{array}{l}0.00619 * \\
(0.00338)\end{array}$ \\
\hline Log of size & $\begin{array}{l}0.579 * * * \\
(0.0134)\end{array}$ & $\begin{array}{l}0.578 * * * \\
(0.0135)\end{array}$ \\
\hline Chain (1=yes) & $\begin{array}{l}0.116 \\
(0.0797)\end{array}$ & $\begin{array}{l}0.114 \\
(0.0790)\end{array}$ \\
\hline Log of size*Chain & $\begin{array}{l}0.0167 \\
(0.0152)\end{array}$ & $\begin{array}{l}0.0170 \\
(0.0150)\end{array}$ \\
\hline Corner (1=yes) & $\begin{array}{l}0.0167 \\
(0.0152)\end{array}$ & $\begin{array}{l}0.00927 \\
(0.0135)\end{array}$ \\
\hline Located in a shopping mall (1=yes) & $\begin{array}{l}0.0643^{* * * *} \\
(0.0234)\end{array}$ & $\begin{array}{l}0.0641 * * * \\
(0.0234)\end{array}$ \\
\hline Shopping district size (in $1,000 \mathrm{~m}^{2}$ ) & $\begin{array}{l}0.000163 * \\
(9.63 \mathrm{e}-05)\end{array}$ & $\begin{array}{l}0.000213 * * \\
(0.000106)\end{array}$ \\
\hline Average income per resident (in 1,000 euros) & $\begin{array}{l}0.000396 \\
(0.00394)\end{array}$ & $\begin{array}{l}0.000584 \\
(0.00394)\end{array}$ \\
\hline Population density per $\mathrm{km}^{2}$ & $\begin{array}{l}-1.22 \mathrm{e}-05^{* * *} \\
(4.45 \mathrm{e}-06)\end{array}$ & $\begin{array}{l}-1.18 \mathrm{e}-05^{* * *} \\
(4.43 \mathrm{e}-06)\end{array}$ \\
\hline Log of distance to train station & $\begin{array}{l}0.00391 \\
(0.0417)\end{array}$ & $\begin{array}{l}0.00482 \\
(0.0422)\end{array}$ \\
\hline Log of distance to water & $\begin{array}{l}0.0335 * * \\
(0.0131)\end{array}$ & $\begin{array}{l}0.0337 * * \\
(0.0131)\end{array}$ \\
\hline New (1=yes) & $\begin{array}{l}0.154 * * * \\
(0.0426)\end{array}$ & $\begin{array}{l}0.155^{* * * *} \\
(0.0429)\end{array}$ \\
\hline Renovated ( $1=$ yes) & $\begin{array}{l}0.151 * * * \\
(0.0445)\end{array}$ & $\begin{array}{l}0.151 * * * \\
(0.0452)\end{array}$ \\
\hline SBI sector classification & yes & yes \\
\hline Building periods & yes & yes \\
\hline Transaction year fixed effects & yes & yes \\
\hline Tenant category fixed effects & yes & yes \\
\hline Urbanity fixed effects & yes & yes \\
\hline PC4 fixed effects & yes & yes \\
\hline Observations & 6,864 & 6,864 \\
\hline Adjusted $R^{2}$ & 0.696 & 0.695 \\
\hline
\end{tabular}

Note: Dependent variable is log of retail rent. This table presents results using alternative indices to measure tenant mix. The first column shows results using Shannon Index, while the second column shows results with weighted Herfindahl Index. Clustered standard errors at PC4 level in parentheses. ${ }^{* * *} p<$ $0.01,{ }^{* *} p<0.05,{ }^{*} p<0.1$ 
alternative tenant mix index by using the Shannon Index, which is another commonly used index for measuring diversity. The Shannon Index is defined as follows:

$$
\text { Shannon Index } \text { Int }=-\sum_{l=1}^{m} P_{l j t} \ln \left(P_{l j t}\right),
$$

where $P_{l j t}$ is the proportion of SBI sector classification $l$ compared to all retail properties within a shopping district $j$ in year t. Shannon Index is very similar to Herfindahl Index but it gives lower weight to SBI sector classifications that account for a large proportion. Shannon Index must be larger than zero, and it increases when a shopping district gets more diverse.

The second alternative tenant mix index we propose is the adjusted, or weighted, Herfindahl Index. Compared with the standard Herfindahl Index we used previously, the weighted Herfindahl Index uses number of jobs as weight for each retail property. Retail properties of different scales play different roles in determining the tenant mix, as well as the attractiveness of a shopping district. To reflect this, we extend the influence of some retail properties, anchor stores for example, on the tenant mix of the shopping district by using number of jobs as weight. Similar as Eq. 1, we take the reciprocal of the weighted Herfindahl Index.

Table 6 presents the regression results using alternative indices. Column (1) depicts results using Shannon Index, while Column (2) uses (the reciprocal of) weighted Herfindahl Index. Both coefficients of tenants mix - alternatively defined are positive and significant. When Shannon Index of a shopping district increases by 1 unit, retail rents increase by about $8.83 \%$. Similarly, retail rents are about $0.62 \%$ higher with 1 unit increment of weighted Herfindahl Index. Both indicates a positive relationship between retail rents and tenant mix. This shows that our results are consistent with the choices of diversity indices. ${ }^{25}$

\section{Conclusion}

This paper investigates the relationship between retail rents and tenant mix for high street shopping districts in which ownership is fragmented and tenant mix is outside the control of individual property investors. Data on high street shopping districts in the Netherlands between 1996 and 2011 reveal that retail rents are significantly related to tenant mix. Shopping districts with greater tenant mix show higher retail rents relative to districts with lower tenant mix. In general, we conclude that there is a positive relationship between tenant mix and retail rents.

Our analysis is based on shopping districts for which boundaries are typically difficult to measure. We argue that our strategy enables the precise delineation of shopping district boundaries. While typical approaches based on all-parcel files provide information on intended land use, it also potentially mismeasures the boundaries of the actual functional economic shopping district. Instead, we propose to use kernel

\footnotetext{
${ }^{25}$ Note that these indices have different scales. Therefore, it would be illogical to compare the coefficients in two columns directly.
} 
density techniques based on granular retail property information to precisely indicate the economic functioning shopping districts. For each of these shopping districts we calculate tenant mix based on SBI sector classification. These sector classifications are commonly used and provide an efficient way of characterizing retail activity. We use the reciprocal of Herfindahl index to determine the tenant mix. We then combine our measures of tenant mix with retail transaction data. Our empirical strategy is based on a set of different regression models. First, we estimate a set of linear regression models for rent transactions currently located in a shopping district. Second, we explore the potential nonlinear relationship between retail rents and tenant mix by estimating a semiparametric model. Third, we exploit the unobserved heterogeneity in retail rents and the variation in the tenant mix of shopping districts by estimating a difference-in-difference model. The main results of tenant mix turn out to be unaffected in the sensitivity analyses. We explore differences across various thresholds and tenant mix indices. Neither of these results jeopardize our main findings.

While our research addresses many of the challenges in estimating tenant mix effects on rents, a number of new directions for future research can be indicated. First, the question arises if heterogeneity in tenants across shopping districts drive these results. Second, tenant mix may in actual fact relate to differences in convenience goods, shopping good, and specialty goods. Third, although we have tried to control for competition between retail tenants, this is not the focus of this paper. The tradeoff between agglomeration and competition and its influence on tenant mix needs further exploration. These, amongst other issues, remain for future research.

Acknowledgments We are grateful for suggestions and comments we received from participants in the Urban and Regional Studies Institute lunch seminar series, the 2018 ERES Conference, the AEW Real Estate Data Lab and the 2019 FSU-UF-UCF Symposium. Our specific thanks go to Wayne Archer, Tingyu Zhou and one anonymous referee for their comments. We would also like to thank John Clapp, Michiel Daams, Ed Nozeman, Xiaolong Liu and Geoffrey Turnbull for their discussions. Finally, we would like to thank Geodienst for GIS data modeling assistance. The authors are responsible for any errors.

Open Access This article is licensed under a Creative Commons Attribution 4.0 International License, which permits use, sharing, adaptation, distribution and reproduction in any medium or format, as long as you give appropriate credit to the original author(s) and the source, provide a link to the Creative Commons licence, and indicate if changes were made. The images or other third party material in this article are included in the article's Creative Commons licence, unless indicated otherwise in a credit line to the material. If material is not included in the article's Creative Commons licence and your intended use is not permitted by statutory regulation or exceeds the permitted use, you will need to obtain permission directly from the copyright holder. To view a copy of this licence, visit http://creativecommonshorg/licenses/by/4.0/.

\section{Appendix A: Theoretical Model}

\section{A.1 Matching Function}

Following the matching framework of Moen (1997), we suppose $M(u, v)$ is the matching function representing the matches of retail property investors and retail tenants, where $u$ is the rate of retail tenants searching for a property (relative to the total 
number of retail tenants) and $v$ is the vacancy rate of retail properties on the market. ${ }^{26}$ Following standard assumptions, we let $M(u, v)$ be an increasing concave function, homogeneous of order one in $(u, v)$, so that we have

$$
g(\theta)=\frac{M(u, v)}{v}=M\left(\frac{u}{v}, 1\right)=M(\theta, 1),
$$

and

$$
h(\theta)=\frac{M(u, v)}{u}=M\left(1, \frac{v}{u}\right)=M\left(1, \frac{1}{\theta}\right),
$$

where $g(\theta)$ is the transition rate of a vacant property becoming occupied, and $h(\theta)$ is the arrival rate of retail tenants finding a vacant property. ${ }^{27} \theta$ is equivalent to $u / v$ which measures the tightness of the market. During recessions of the market, the number of retail tenants who search for vacant properties $(u)$ decreases and the number of vacant properties $(v)$ increases, which leads $\theta$ and $g(\theta)$ to decrease. ${ }^{28}$ The opposite happens during booming periods of the market.

After having been matched, the retail tenant considers consumers' demand as well as tenant mix in the shopping district and starts to conduct one type of retail activitiy immediately. Meanwhile, there are also some occupied retail properties that break down and decide to end their rental contract. As a result, these retail properties enter the market to join the matching process again. We suppose this happens at a constant rate $\delta$, which is determined exogenously. Therefore, occupied properties become vacant at rate $\delta(1-v)$. In steady state, the matching rate and breaking down rate are equivalent, so that

$$
M(u, v)=\delta(1-v) .
$$

Since $M(u, v)$ can be written as $g(\theta) v$, we get

$$
g(\theta) v=\delta(1-v) .
$$

Rewrite this and we get

$$
v=\frac{\delta}{g(\theta)+\delta} .
$$

Equation 5 is the steady state vacancy rate, which is determined by the transition rate $g(\theta)$ and breaking down rate $\delta$.

\section{A.2 Retail Property Investors}

Retail property investors own retail properties. When a retail property is occupied, investors obtain rental income from the retail tenant who rents this property. If the retail property is vacant, investors have to search for a retail tenant at a cost. This cost consists of two parts, search cost and management cost for holding a vacant property.

\footnotetext{
${ }^{26}$ The matching function $M(u, v)$ captures the frictions of the market. The frictions come from search costs and time delays during the search process.

${ }^{27}$ Clearly, we can see that $g(\theta)=\theta h(\theta)$.

${ }^{28} g(\theta)$ is positively related to $\theta$ because when there are more searching retail tenants relative to vacant properties, vacant properties can be rented out more easily. On the contrary, $h(\theta)$ is negatively related to $\theta$. When there are more searching retail tenants relative to vacant properties, it is more difficult for a retail tenant to find a vacant property.
} 
Let $I_{v}$ denote the expected discounted profits of investors with vacant properties and $I_{O}$ denote the expected discounted profits of investors that own occupied properties. The present value of $I_{v}$ is represented as follows:

$$
\sigma I_{v}=-c+g(\theta)\left(I_{o}-I_{v}\right),
$$

where $\sigma$ is the discount rate and $c$ is the cost for investors with vacant properties. $g(\theta)\left(I_{o}-I_{v}\right)$ represents the expected gain from renting out a property. The expected profit of holding a vacant property equals the expected gain from matching minus the cost of holding a vacant property. Similarly, the expected discounted profits of investors with occupied properties, $I_{o}$, can be written as:

$$
\sigma I_{o}=r-\delta\left(I_{o}-I_{v}\right),
$$

where $r$ is the rent of an occupied property. $\delta\left(I_{o}-I_{v}\right)$ measures the loss if an occupied property becomes vacant. The expected discounted profit of an investor with an occupied property equals the rent of this property minus the expected loss if this property becomes vacant. Based on Eqs. 6 and 7, we can get

$$
\sigma I_{v}=\frac{g(\theta) r-c(\sigma+\delta)}{\sigma+\delta+g(\theta)} .
$$

Rearranging this yields

$$
g(\theta)=(\sigma+\delta) \frac{\sigma I_{v}+c}{r-\sigma I_{v}} .
$$

From Eq. 9, we can see that $g(\theta)$ is negatively related to $r$. This indicates a negative relationship between the prosperity measure of the market, $\theta$, and retail rents, $r$. When $\theta$ is small, it means the market is in a depression period with a lot of vacant retail properties and thus retail rents will be relatively low.

\section{A.3 Retail Tenants}

Once retail tenants find a vacant retail property, they will start their retail activity immediately. However, the choice of the type of retail activity depends on consumers' needs and tenant mix of the shopping district. Because of the existence of shopping externalities, a retail tenants must take other retail tenants in the proximity into account when deciding on their business type. We suppose $f(m ; X)$ to be the production function of a retail tenant, where $m$ is the shopping district's tenant mix and $X$ represents all other input factors of the production function. ${ }^{29}$ We assume the firstorder derivative of $f(m)$ exists. Retail tenants can only start their retail activity after finding a retail property. The expected profit of a retail tenant who has not found a property is equivalent to its expected capital gain from property search minus its search costs. If the expected discounted profit of a retail tenant who has not found a property is $P_{v}$, then we get

$$
\sigma P_{v}=-z+h(\theta)\left(P_{o}-P_{v}\right)
$$

\footnotetext{
${ }^{29} \mathrm{We}$ assume tenant mix $m$ of a retail tenant is exogenous, which means $m$ is independent of all other input factors, $X$. Both $m$ and $X$ are non-negative. Since our focus is on tenant mix, in the following context we write the production function as $f(m)$. This does not affect conclusion.
} 
where $z$ is the search cost of tenants and $P_{o}$ is the expected discounted profit of a retail tenant who has a shop. $h(\theta)\left(P_{o}-P_{v}\right)$ is the expected capital gain from searching. Similarly, we can get the equation of $P_{o}$ as

$$
\sigma P_{o}=f(m)-r-\delta\left(P_{o}-P_{v}\right) .
$$

$f(m)-r$ is the net return of a retail tenant conducting retail activity. Its expected discounted profit equals its net return minus the expected loss of breaking down.

Since the market is competitive and retail tenants can enter the market freely, in equilibrium the expected profit of a retail tenant who is searching for a property must be equivalent to zero, which means $P_{v}=0$. Substituting this into Eqs. 10 and 11, we can get

$$
P_{o}=\frac{z}{h(\theta)}=\frac{f(m)-r}{\sigma+\delta} .
$$

\section{A.4 Equilibrium}

We assume that rents are determined by Nash bargaining. The solution to Nash bargaining, $r^{*}$ should maximize the product of investors' and tenants' profits from the matching process weighted by their bargaining power. Let $\beta$ represent the bargaining power of retail tenants, and $(1-\beta)$ be the bargaining power of retail property investors, where $0<\beta<1$. According to Nash bargaining, there exists a rent level $r^{*}$ which solves the problem

$$
\max _{r}\left(I_{o}-I_{v}\right)^{1-\beta}\left(P_{o}-P_{v}\right)^{\beta} .
$$

Taking the first derivative, we get

$$
(1-\beta)\left(P_{o}-P_{v}\right)=\beta\left(I_{o}-I_{v}\right) .
$$

Note that in equilibrium $P_{v}=0$. Combine this equation with Eqs. 5, 8 and 12, we are able to calculate the equilibrium rent $r^{*}$ :

$$
r^{*}=\frac{(1-\beta)(\sigma+\delta+g(\theta)) f(m)-\beta c(\sigma+\delta)}{\sigma+\delta+(1-\beta) g(\theta)} .
$$

This indicates that the equilibrium rent $r^{*}$ is related to tenant mix.

Take the first derivative of $r^{*}$ over tenant mix $m$, and we get

$$
\frac{d r^{*}}{d m}=A \frac{d f(m)}{d m}
$$

where $A=\frac{(1-\beta)(\sigma+\delta+g(\theta))}{\sigma+\delta+(1-\beta) g(\theta)}$. Note that $A>0$, so that the signal of Eq. 16 depends on the signal of $\frac{d f(m)}{d m}$, which measures the relationship between the retail tenant's 
production function and tenant mix. This indicates that retail rent is indeed affected by the tenant mix of the shopping district, but the overall effect remains indecisive. It is the aim of our empirical analysis to answer the question with regard to the relationship between retail rents and tenant mix.

\section{Appendix B: Data Appendix}

\section{B.1 Retail Properties}

The granular data of registered retail properties come from the Dutch Chambers of Commerce. These datasets are collected annually from 1996 to 2011 and include all retail properties registered at the Dutch Chambers of Commerce in the corresponding year. For each retail property, we know its precise location, SBI sector classification, and number of jobs. Figure 2 illustrates the locations of all registered retail properties in 2011.

\section{B.2 Shopping Districts}

Shopping districts are constructed based on the spatial distribution of retail properties. We use GIS techniques to delineate shopping districts. The procedure consists of the following steps. First, we create grids of 10 by 10 meters for all of the Netherlands. Next, for each grid we calculate the density of retail properties within 100 meters of the grid by using the method of kernel density. When calculating the density, we take the number of jobs at each retail property as the weight for each property. The choice of using number of jobs as the weight of each retail property has practical reasons. We experimented both with the weights and without the weights. When no weights are used, grids located at the edge of a shopping district usually have a lowdensity value, so that constructed shopping districts are smaller than their actual size. This has serious consequences in the later stage of our empirical analysis, because retail properties at the edge of a shopping district are often excluded from the corresponding shopping district. Conversely, this problem may be relieved when the weights are used. Then, we use a predetermined threshold of density and, for adjacent grids with density exceeding this threshold, we merge them to create a shopping district. We set this threshold of density to be 3,421 jobs per $\mathrm{km}^{2}$, which is equivalent to the 65 th percentile of the retail property density distribution in 2010 . We apply the same procedures to construct shopping districts for every year between 1996 and 2011. In this way, we are able to capture the development of shopping districts over time. Figure 4 shows all shopping districts constructed in the Netherlands in 2011. Figure 5 shows the development of shopping districts in the city of Groningen from 1996 to 2011 . The left panel shows the shopping districts in Groningen in 1996, while the right panel shows the shopping districts in 2011. Comparing these two maps, one observes changes in shopping districts over time. 


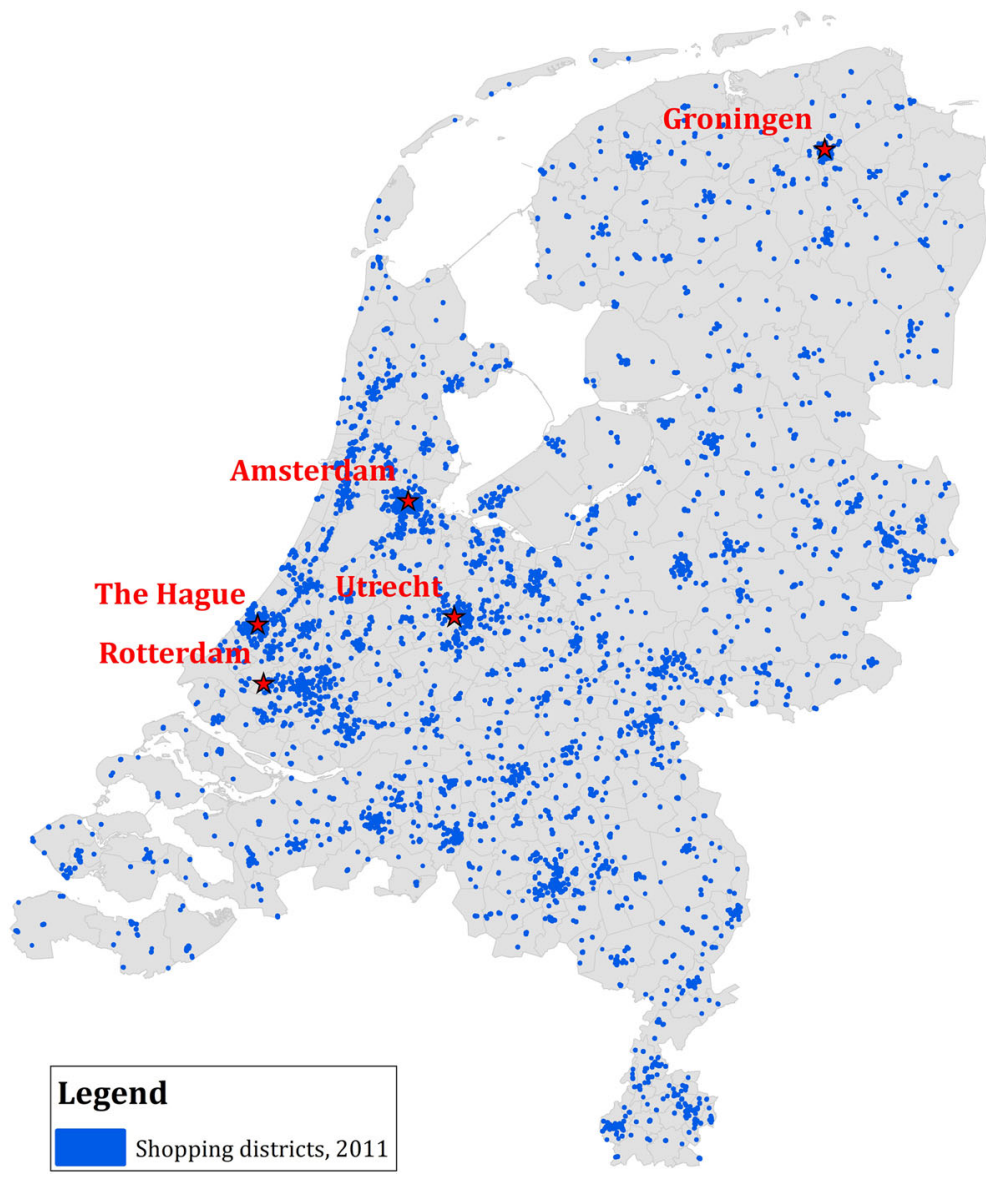

Fig. 4 Shopping districts of the Netherlands, 2011

\section{B.3 Rental Transactions}

Our data on retail rents come from Strabo. The data include 9,436 rental transactions for the Dutch retail markets from 1996 to 2011 . All these observations refer to new rental contracts, which means extensions of existing rental contracts are not included in the data. The data include information on annual rent, property size, precise location, name of the tenant and year of transaction. Retail rents are nominal market rents. ${ }^{30}$ We geocode all rental transactions and subsequently map these to the all-

\footnotetext{
${ }^{30}$ In the Netherlands, rents typically relate to nominal fixed rents with annual rent increases (at least till 2013). Furthermore, rents relate to market rents so that no information on rent incentive is known.
} 


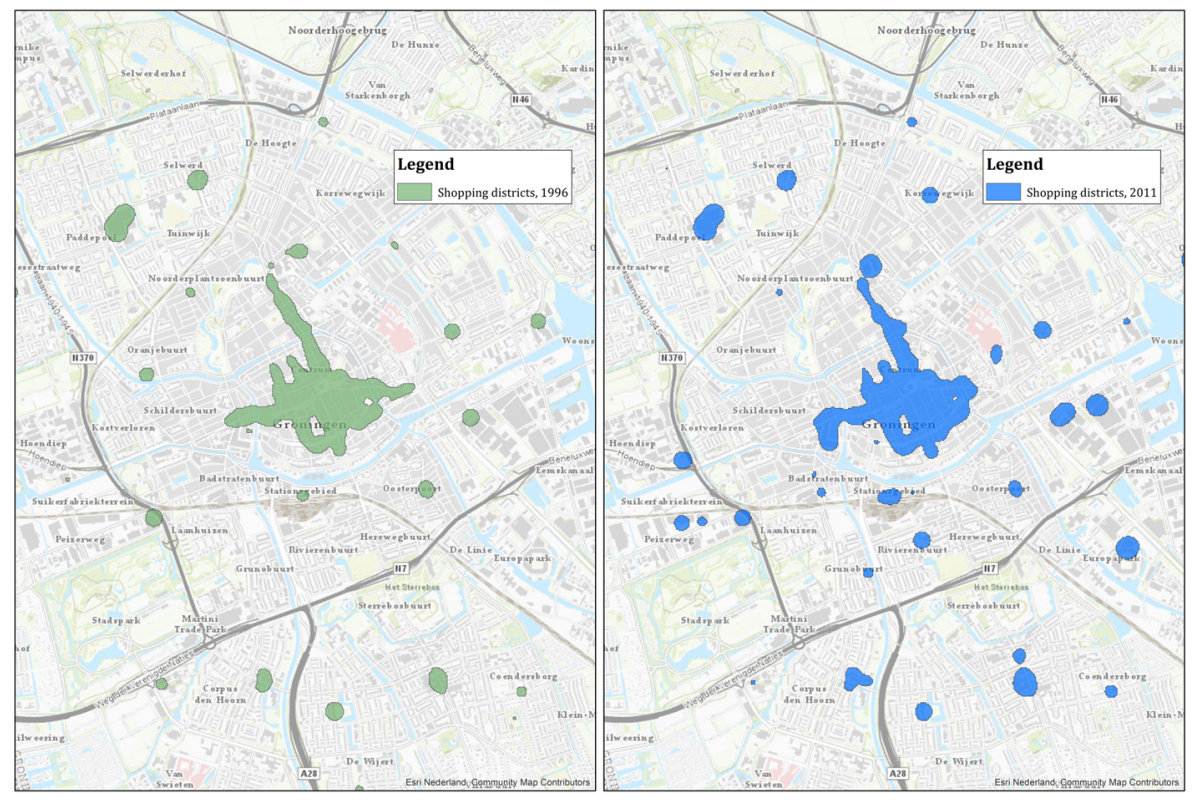

Fig. 5 Shopping districts of Groningen, 1996 and 2011

parcel file of the Netherlands (BAG data). Finally, we map our rental transaction data onto the shopping districts in the year the property was transacted. Figure 6 shows the locations of all these rental transactions.

Out of these observations, we have 6,864 rental transactions which are in a shopping district when transacted. These rental transactions are used in the hedonic model analysis. Figure 7 compares the trends in average annual rent (per $\mathrm{m}^{2}$ ) for rental transactions located in a shopping district when transacted and those not. It can be seen that the trends in both panels of Fig. 7 follow similar pattern. Especially the average annual rent per $m^{2}$ of properties located in a shopping district when transacted is almost twice that of properties that are not in a shopping district when transacted.

Because of the limited number and distribution of our rental transactions, only some of the shopping districts incorporate rental transactions. However, it is important to know the percentage of our occupied shopping district (i.e. shopping districts with at least one rental transaction in it) out of all shopping districts in the Netherlands in each year. To do so, we calculate the size of all shopping districts and the size of occupied shopping districts for each year. The result is presented in Fig. 8. We can see that the overall size of shopping districts in the Netherlands increases gradually from 1996 to 2011. However, the size of occupied shopping districts in each year fluctuates around 20,000,000 square meters. The grey line in the graph shows the percentage of the size of occupied shopping districts out of the size of all shopping districts. It is apparent that this line fluctuates around $30 \%$. 


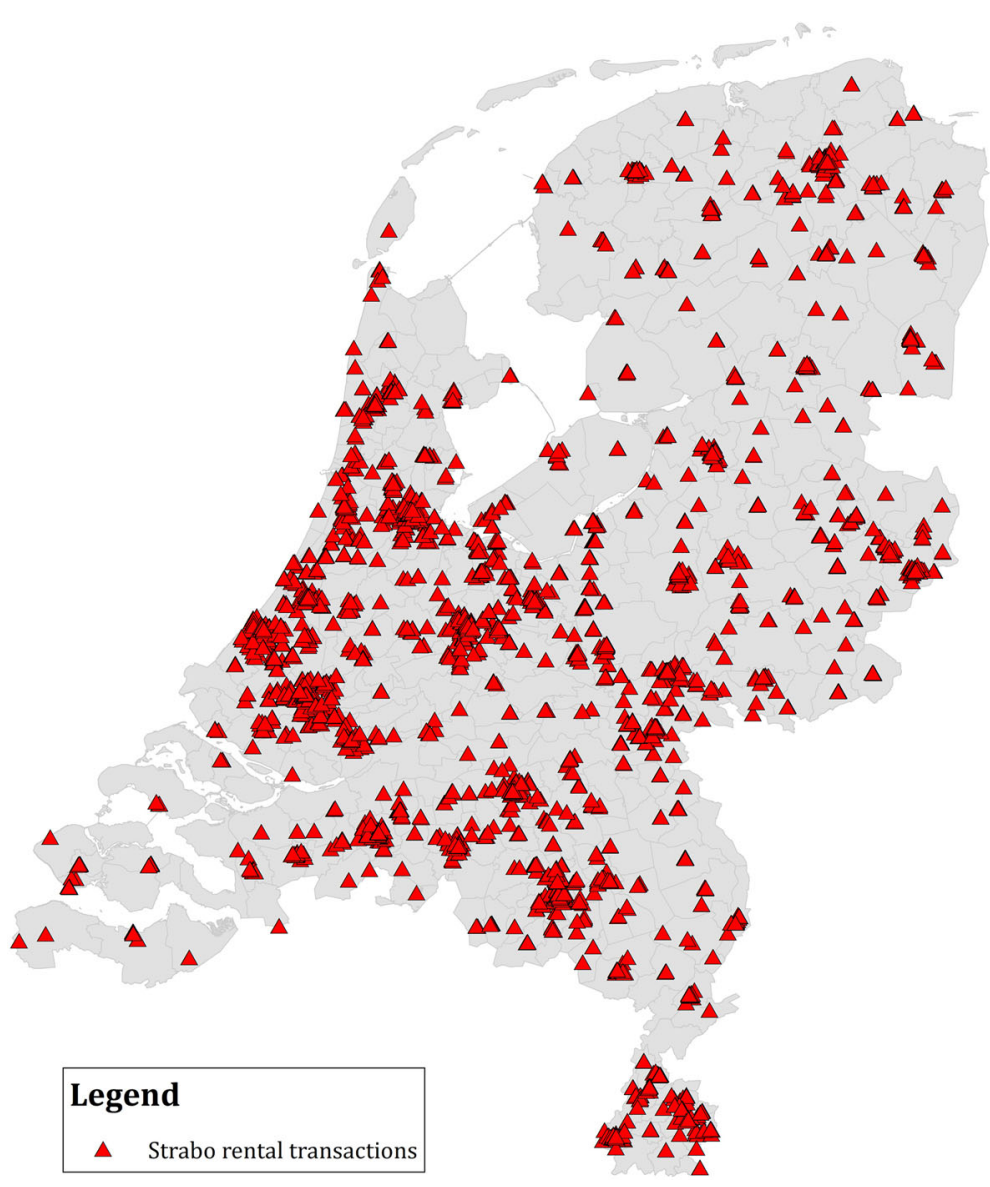

Fig. 6 Location of all rental transactions from 1996 to 2011 

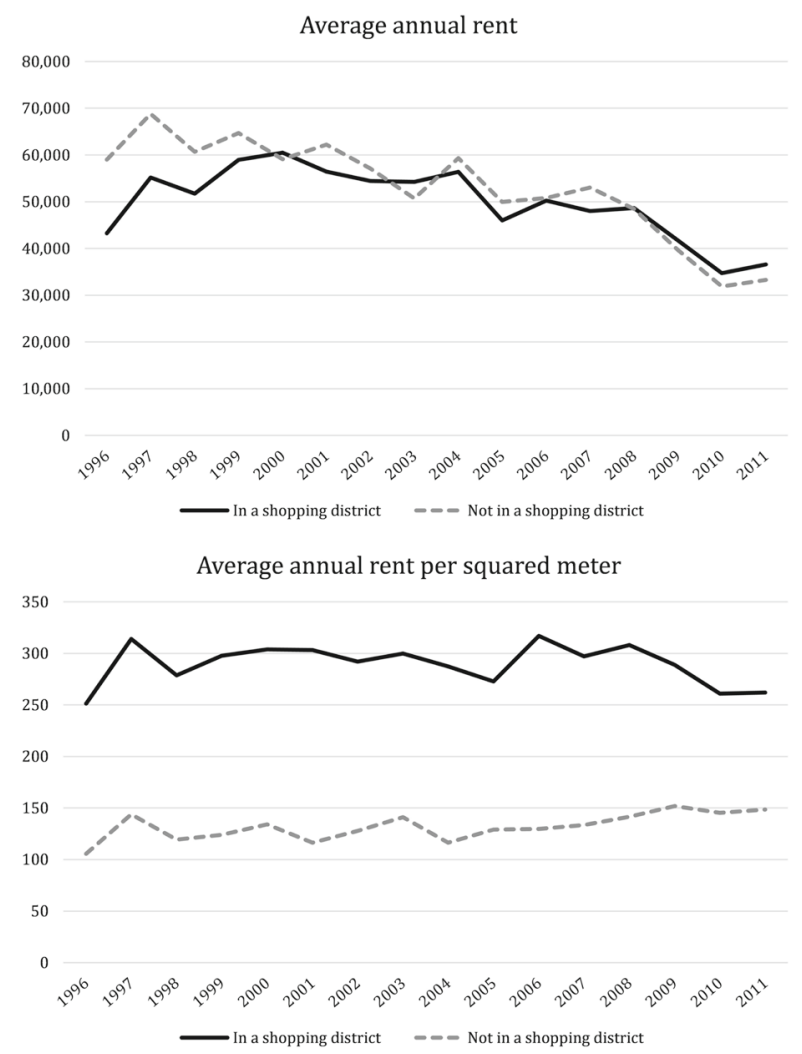

Fig. 7 The development of average annual rents

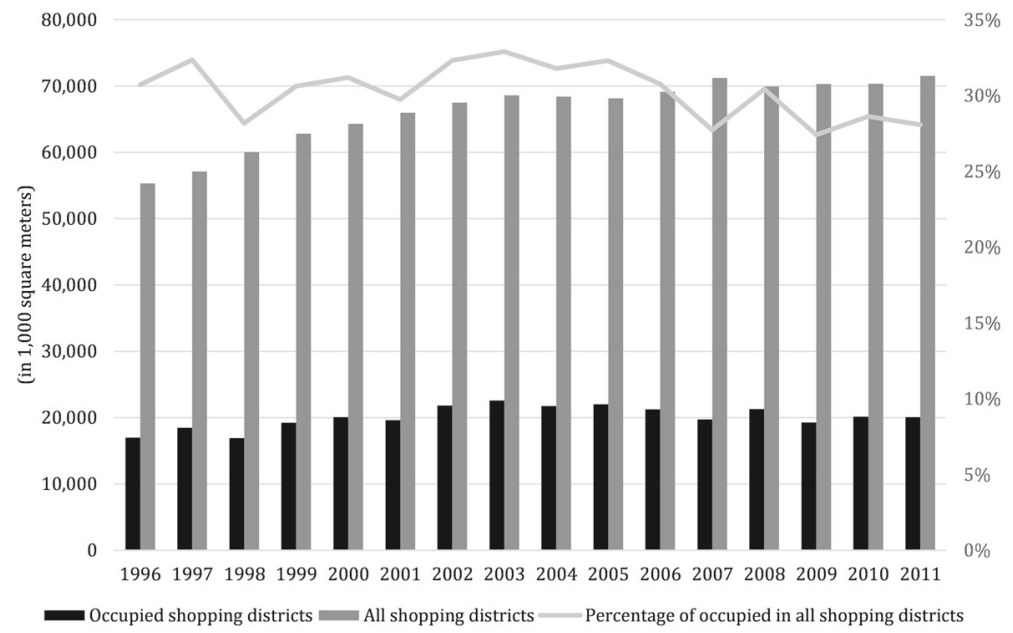

Fig. 8 Shopping districts with at least one rental transaction observed versus all shopping districts from 1996 to 2011 


\section{Appendix C: Different Specifications of the Hedonic Price Model}

Table 7 Different specifications of the hedonic price model

\begin{tabular}{|c|c|c|}
\hline & (1) & (2) \\
\hline & Quadratic form & Categorized tenant mix \\
\hline \multirow[t]{2}{*}{$M I X$} & $0.0229 * * *$ & \\
\hline & $(0.00815)$ & \\
\hline \multirow[t]{2}{*}{$M I X^{2}$} & $-0.000431^{* *}$ & \\
\hline & $(0.000180)$ & \\
\hline \multicolumn{3}{|c|}{ Categorized $M I X$ (reference: $M I X<12$ ) } \\
\hline \multirow{2}{*}{ Dummy $(12 \leq M I X<25)$} & & $0.125 * * *$ \\
\hline & & $(0.0470)$ \\
\hline \multirow[t]{2}{*}{ Dummy $(25 \leq M I X<35)$} & & $0.115^{* *}$ \\
\hline & & $(0.0499)$ \\
\hline \multirow[t]{2}{*}{ Dummy $(M I X \leq 35)$} & & 0.0854 \\
\hline & & $(0.0630)$ \\
\hline SBI sector classification & yes & yes \\
\hline Building characteristics & yes & yes \\
\hline Building periods & yes & yes \\
\hline Transaction year fixed effects & yes & yes \\
\hline Tenant category fixed effects & yes & yes \\
\hline Urbanity fixed effects & yes & yes \\
\hline PC4 fixed effects & yes & yes \\
\hline Observations & 6,864 & 6,864 \\
\hline Adjusted $R^{2}$ & 0.696 & 0.695 \\
\hline
\end{tabular}

Note: Dependent variable is log of retail rent. This table represents results based on other specifications of the hedonic price model. The first column include results using the quadratic MIX. The second column shows results using categorized tenant mix. Both results show possibility of a nonlinear relationship between tenant mix and retail rents. Clustered standard errors at PC4 level in parentheses. ${ }^{* * *} p<0.01$, ${ }^{* *} p<0.05,{ }^{*} p<0.1$ 


\section{Appendix D: Descriptive Statistics of Rental Transactions used in Difference-in-Difference Analysis}

Table 8 Descriptive statistics of rental transactions used in difference-in-difference analysis

\begin{tabular}{|c|c|c|c|c|c|}
\hline & Mean & Std. Dev. & Median & Min & Max \\
\hline Rent price & $50,429.140$ & $43,390.420$ & 36,302 & 9,000 & 338,380 \\
\hline Rent price per $m^{2}$ & 242.345 & 188.783 & 189 & 16 & 2,351 \\
\hline $\operatorname{MIX}$ & 15.927 & 11.041 & 19.674 & 1 & 40.806 \\
\hline Property size $\left(m^{2}\right)$ & 324.686 & 447.309 & 180 & 20 & 8,390 \\
\hline Transaction year & 2003.581 & 4.493 & 2004 & 1996 & 2011 \\
\hline $\begin{array}{l}\text { Average income per resident } \\
\text { (in } 1,000 \text { euros) }\end{array}$ & 15.203 & 6.018 & 13.75 & 0 & 45.5 \\
\hline Population density per $\mathrm{km}^{2}$ & $5,815.817$ & $3,755.953$ & 5,337 & 2.00 & 28,060 \\
\hline Distance to train station $(m)$ & $1,998.303$ & $3,129.482$ & 893.559 & 27.268 & $22,766.360$ \\
\hline Distance to water $(m)$ & 222.054 & 171.956 & 181.425 & 2.265 & $1,180.464$ \\
\hline Chain store (1=yes) & 0.367 & 0.482 & & & \\
\hline Corner store (1=yes) & 0.145 & 0.353 & & & \\
\hline Located in a shopping mall (1=yes) & 0.209 & 0.407 & & & \\
\hline$S D$ & 0.828 & 0.378 & & & \\
\hline$S$ & 0.702 & 0.458 & & & \\
\hline \multicolumn{6}{|l|}{ Building status } \\
\hline Existing (1=yes) & 0.906 & & & & \\
\hline New (1=yes) & 0.075 & & & & \\
\hline Renovated (1=yes) & 0.019 & & & & \\
\hline \multicolumn{6}{|l|}{ Building periods } \\
\hline$<1945$ & 0.423 & & & & \\
\hline $1945-1960$ & 0.122 & & & & \\
\hline $1961-1970$ & 0.065 & & & & \\
\hline 1971-1980 & 0.077 & & & & \\
\hline $1981-1990$ & 0.062 & & & & \\
\hline $1991-2000$ & 0.113 & & & & \\
\hline$>2000$ & 0.138 & & & & \\
\hline Number of rental transactions & 7,963 & & & & \\
\hline
\end{tabular}

Note: This table presents statistics of observations used in the difference-in-difference analysis. In our baseline regression, we use only rental transactions that are located in a shopping district when transacted. However, based on our difference-in-difference setting, here we include all rental transactions but, for retail properties that has ever been or will be included in a shopping district, we exclude those ones built after the shopping district is formed. 


\section{References}

Abratt, R., Fourie, J., Pitt, L. (1985). Tenant mix: the key to a successful shopping centre. Quarterly Review of Marketing, 10(3), 19-26.

Ahlfeldt, G.M., Redding, S.J., Sturm, D.M., Wolf, N. (2015). The economics of density: Evidence from the Berlin wall. Econometrica, 83(6), 2127-2189.

Ambrose, B., Shafer, M., Yildirim, Y. (2016). The impact of tenant diversification on spreads and default rates for mortgages on retail properties. The Journal of Real Estate Finance and Economics, 56(1), $1-32$.

Arzaghi, M., \& Henderson, J.V. (2008). Networking off Madison Avenue. Review of Economic Studies, 75(4), 1011-1038.

Bajari, P., \& Kahn, M.E. (2005). Estimating housing demand with an application to explaining racial segregation in cities. Journal of Business \& Economic Statistics, 23(1), 20-33.

Been, V., Ellen, I.G., Gedal, M., Glaeser, E., McCabe, B.J. (2016). Preserving history or restricting development? The heterogeneous effects of historic districts on local housing markets in New York City. Journal of Urban Economics, 92, 16-30.

Benjamin, J.D., Boyle, G.W., Sirmans, C. (1992). Price discrimination in shopping center leases. Journal of Urban Economics, 32(3), 299-317.

Bin, O. (2005). A semiparametric hedonic model for valuing wetlands. Applied Economics Letters, 12(10), 597-601.

Bontemps, C., Simioni, M., Surry, Y. (2008). Semiparametric hedonic price models: assessing the effects of agricultural nonpoint source pollution. Journal of Applied Econometrics, 23(6), 825-842.

Brueckner, J.K. (1993). Inter-store externalities and space allocation in shopping centers. The Journal of Real Estate Finance and Economics, 7(1), 5-16.

Cho, H., \& Shilling, J.D. (2007). Valuing retail shopping center lease contracts. Real Estate Economics, 35(4), 623-649.

Claycombe, R.J. (1991). Spatial retail markets. International Journal of Industrial Organization, 9(2), 303-313.

Colwell, P., \& Munneke, H. (1998). Percentage leases and the advantages of regional malls. Journal of Real Estate Research, 15(3), 239-252.

Daams, M.N., Sijtsma, F.J., Van der Vlist, A.J. (2016). The effect of natural space on nearby property prices: Accounting for perceived attractiveness. Land Economics, 92(3), 389-410.

Des Rosiers, F., Thériault, M., Lavoie, C. (2009). Retail concentration and shopping center rents-a comparison of two cities. Journal of Real Estate Research, 31(2), 165-208.

Dolega, L., Pavlis, M., Singleton, A. (2016). Estimating attractiveness, hierarchy and catchment area extents for a national set of retail centre agglomerations. Journal of Retailing and Consumer Services, $28,78-90$.

Eaton, B.C., \& Lipsey, R.G. (1982). An economic theory of central places. The Economic Journal, 92(365), 56.

Evers, D. (2002). The rise (and fall?) of national retail planning. Tijdschrift voor Economische en Sociale Geografie, 93(1), 107-113.

François, R., Marius, T., Laurent, M. (2005). Spatial versus non-spatial determinants of shopping center rents: modeling location and neighborhood-related factors. Journal of Real Estate Research, 27(3), 293-320.

Gatzlaff, D., Sirmans, S., Diskin, B. (1994). The effect of anchor tenant loss on shopping center rents. Journal of Real Estate Research, 9(1), 99-110.

Gerbich, M. (1998). Shopping center rentals: An empirical analysis of the retail tenant mix. Journal of Real Estate Research, 15(3), 283-296.

Glaeser, E.L., Kolko, J., Saiz, A. (2001). Consumer city. Journal of Economic Geography, 1(1), 27-50.

Gould, E.D., Pashigian, B.P., Prendergast, C.J. (2005). Contracts, externalities, and incentives in shopping malls. Review of Economics and Statistics, 87(3), 411-422.

Koster, H.R.A., Pasidis, I., Van Ommeren, J. (2019). Shopping externalities and retail concentration: Evidence from Dutch shopping streets. Journal of Urban Economics, 114, 103194.

Koster, H.R.A., \& Rouwendal, J. (2012). The impact of mixed land use on residential property values. Journal of Regional Science, 52(5), 733-761.

Koster, H.R.A., Van Ommeren, J., Rietveld, P. (2014). Agglomeration economies and productivity: A structural estimation approach using commercial rents. Economica, 81(321), 63-85. 
Lloyd, A., \& Cheshire, J. (2017). Deriving retail centre locations and catchments from geo-tagged twitter data. Computers, Environment and Urban Systems, 61, 108-118.

Miceli, T.J., \& Sirmans, C.F. (1995). Contracting with spatial externalities and agency problems the case of retail leases. Regional Science and Urban Economics, 25(3), 355-372.

Moen, E.R. (1997). Competitive search equilibrium. Journal of Political Economy, 105(2), 385-411.

Neumark, D., \& Kolko, J. (2010). Do enterprise zones create jobs? Evidence from California's enterprise zone program. Journal of Urban Economics, 68(1), 1-19.

Nozeman, E.F., \& Van der Vlist, A.J. (2014). European Metropolitan Commercial Real Estate Markets: Springer.

Pashigian, B.P., \& Gould, E.D. (1998). Internalizing externalities: the pricing of space in shopping malls. The Journal of Law and Economics, 41(1), 115-142.

Roig-Tierno, N., Baviera-Puig, A., Buitrago-Vera, J., Mas-Verdu, F. (2013). The retail site location decision process using GIS and the analytical hierarchy process. Applied Geography, 40, 191-198.

Sheppard, S. (1999). Hedonic analysis of housing markets. In Cheshire, P., \& Mills, E.S. (Eds.) Applied Urban Economics, volume 3 of Handbook of Regional and Urban Economics, chapter 41 (pp. 15951635): Elsevier.

Sirmans, C.F., \& Guidry, K. (1993). The determinants of shopping center rents. Journal of Real Estate Research, 8(1), 107-115.

Stahl, K. (1982). Location and spatial pricing theory with nonconvex transportation cost schedules. The Bell Journal of Economics, 13(2), 575.

Teller, C., \& Reutterer, T. (2008). The evolving concept of retail attractiveness: What makes retail agglomerations attractive when customers shop at them? Journal of Retailing and Consumer Services, 15(3), 127-143.

Teulings, C.N., Ossokina, I.V., Svitak, J. (2018). The urban economics of retail. CPB Discussion Paper No. 352.

Van der Krabben, E. (2009). Retail development in the Netherlands: Evaluating the effects of radical changes in planning policy. European Planning Studies, 17(7), 1029-1048.

Van der Vlist, A.J., Francke, M., Schoenmaker, D. (2019). Agglomeration economics and capitalization rates: Evidence from the Dutch real estate office market. Working paper.

Van Duijn, M., Rouwendal, J., Boersema, R. (2016). Redevelopment of industrial heritage: Insights into external effects on house prices. Regional Science and Urban Economics, 57, 91-107.

Wheaton, W.C. (2000). Percentage rent in retail leasing: The alignment of landlord-tenant interests. Real Estate Economics, 28(2), 185-204.

Yatchew, A. (1997). An elementary estimator of the partial linear model. Economics Letters, 57(2), 135143.

Yatchew, A. (1998). Nonparametric regression techniques in economics. Journal of Economic Literature, 36(2), 669-721.

Yuo, T.S.-T., Lizieri, C., McCann, P., Crosby, N. (2010). Rental values in UK shopping malls. Urban Studies, 48(8), 1667-1679.

Publisher's Note Springer Nature remains neutral with regard to jurisdictional claims in published maps and institutional affiliations. 